\section{Western Greece and Ionian Sea petroleum systems}

Vassilis Karakitsios

\section{ABSTRACT}

In western Greece, the Ionian and pre-Apulian zones represent, respectively, the basin and the transitional zone (slope) to the Apulian platform. The Apulian platform constitutes the weakly deformed foreland of the external Hellenides. The pre-Apulian zone appears in the Ionian Islands and the eastern Ionian Sea, whereas the Apulian platform is exclusively found in the Ionian Sea. The Ionian zone consists of Triassic evaporites, Jurassicupper Eocene (mostly pelagic carbonates, minor cherts, and shales), overlain by the Oligocene flysch. Organic-rich source rocks occur within Triassic evaporites and Jurassic-Cretaceous pelagic argillaceous-siliceous rocks. The pre-Apulian zone consists of Triassic to Miocene deposits, mainly mixed neritic-pelagic carbonates. Hydrocarbon source rocks include pelagic and hemipelagic deposits rich in marine organic material, although terrigenous organic matter is also found in siliciclastic layers. Apulian platform source rocks are mainly the organic-rich shales within the Triassic Burano evaporites.

Western Greece contains major petroleum systems, which extend into the Ionian Sea. Ionian, pre-Apulian, and Apulian petroleum systems contribute to the probable hydrocarbon accumulations within the big offshore (Ionian Sea) anticlines.

Western Greece contains important oil and gas shale reservoirs with a potential of unconventional exploration. Promising areas for hydrocarbons need systematic and detailed threedimensional seismic data. Exploration for conventional petroleum reservoirs, through the interpretation of seismic profiles and the abundant surface geologic data, will provide the subsurface geometric characteristics of the unconventional reservoirs. Their exploitation should follow that of conventional hydrocarbons to benefit from the anticipated technological advances, eliminating environmental repercussions.

\section{AUTHOR}

VASSILIS KARAKITSIOS $~$ Department of Geology and Geoenvironment, National and Kapodistrian University of Athens, Panepistimioupoli, 15784 Athens, Greece; vkarak@geol.uoa.gr

Vassilis Karakitsios received his diploma in geology (1976) from the University of Athens, and his M.S. degree (1977) and doctorat de 3e cycle (1979) in structural geology, and his Ph.D. (1990) in earth sciences from the Pierre et Marie Curie (Paris 6) University. He is a professor and director at the Department of Historical Geology and Paleontology, and the president of the Hellenic Sedimentological Association. His professional experience includes stratigraphy and tectonics, basin analysis, and petroleum geology of the eastern Mediterranean.

\section{ACKNOWLEDGEMENTS}

This research has been cofinanced by the European Union (European Social Fund) and Greek National Funds through the Operational Program "Education and Lifelong Learning" of the National Strategic Reference FrameworkResearch Funding Program THALIS-University of Athens-Messinian Salinity Crisis: the greatest Mediterranean environmental perturbation and its repercussions to the biota (MIS 375405). I thank E. Kokinou for permission to publish the interpreted seismic profile of Figure 14, as well as F. Marnelis, F. M. Roure, and A. Zelilidis for their helpful reviews.

I also thank F. P. Whitehurst, consulting geologist for AAPG, whose helpful comments improved the text and figures of this paper.

The AAPG Editor thanks the following reviewers for their work on this paper: Fedon Marnelis, Francois M. Roure, and Avram Zelilidis. 


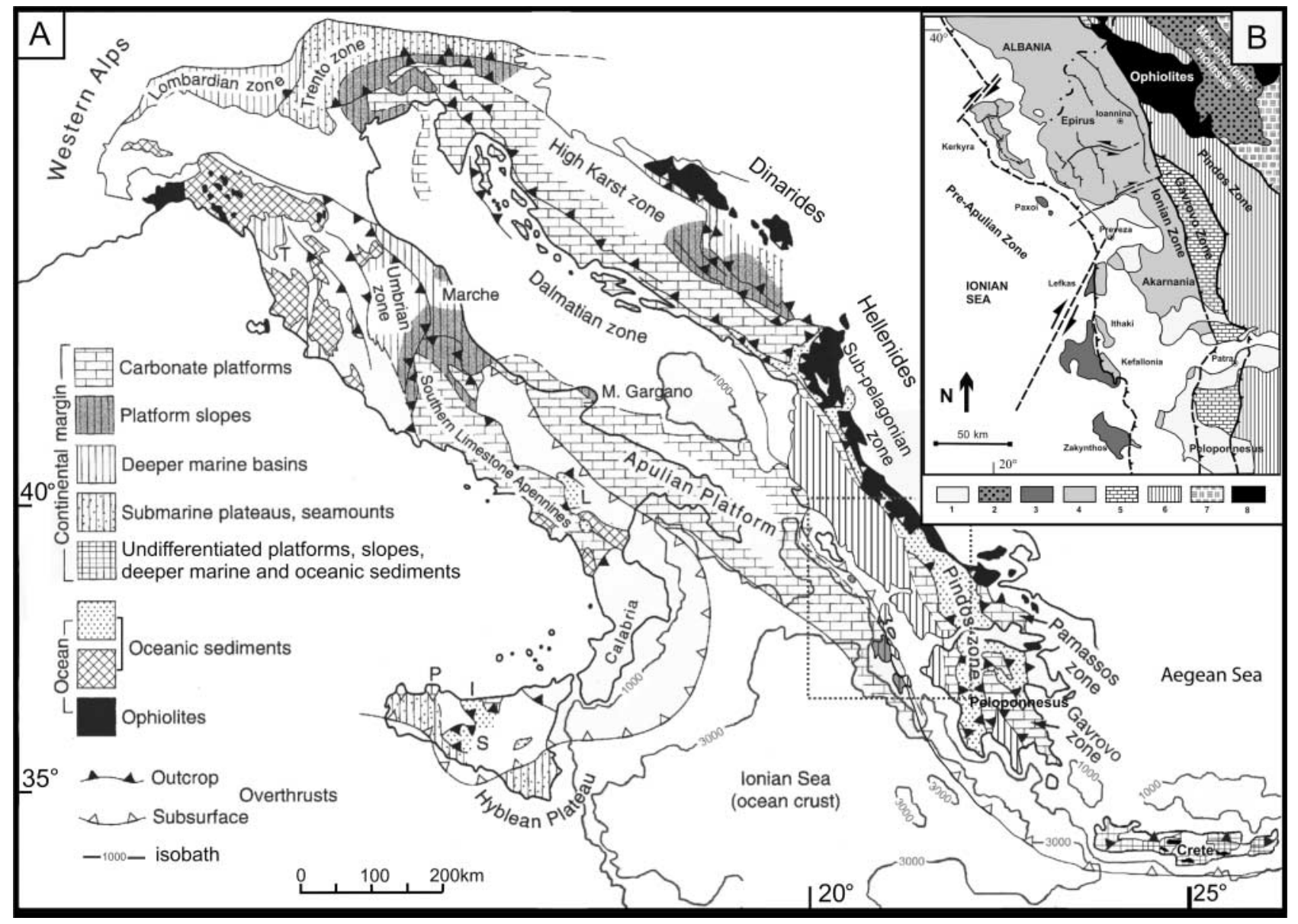

Figure 1. (A) Tectonic units and Late Jurassic paleogeography of the peri-Adriatic area (without palinspastic restoration), and the distribution of isolated Bahamian-type carbonate platforms surrounded by deeper basins (modified from Bernoulli, 2001). (B) Simplified geologic map of western Greece. (1) Neogene and Quaternary post-Alpine sediments. (2) Meso-Hellenic molasses. (3) Pre-Apulian (Paxos) zone. (4) Ionian zone. (5) Gavrovo-Tripolis zone. (6) Pindos zone. (7) Sub-Pelagonian zone. (8) Ophiolites (modified from Karakitsios and Rigakis, 2007).

\section{INTRODUCTION}

Even when the scientific knowledge and research in Greece was very limited, the existence of petroleum in western Greece (Figures 1A, B) was widely known because of the great number of surface oil shows, for example, in the Epirus region (Figure 2), the Keri oil seep on Zakynthos Island, first mentioned by Herodotus (484-430 B.C.), the oil shows in Kyllini (northwestern Peloponnesus), and others. Systematic research since 1960 (IGRS-IFP, 1966; BP, 1971; Monopolis, 1977; Chiotis, 1983; C. Nikolaou, 1986, personal communication; Palakas et al., 1986; Karakitsios, 1992, 1995; Roussos and Marnelis, 1995; Karakitsios and Rigakis, 1996; Rigakis and Karakitsios, 1998; Karakitsios et al., 2001; Zelilidis et al., 2003; Rigakis et al., 2004; Karakitsios and Rigakis, 2007; Marnelis et al., 2007) has proven now that western Greece is characterized by rich source rocks of significant thickness, located in the Ionian and pre-Apulian (Paxos) zones. Limited early exploration focused on the abundant oil shows (Monopolis, 1977), and more recent exploration did not give encouraging results (Xenopoulos, 2000), although both Albania and Italy host substantial oil and gas fields (Mattavelli and Novelli, 1990; Van Greet et al., 2002; Mavromatidis et al., 2004; Roure et al., 2004; Graham Wall et al., 2006; Vilasi et al., 2009; Maravelis et al., 2012). The hydrocarbon exploration in Greece, which was interrupted for more than $10 \mathrm{yr}$, is now commencing again.

The discovery of hydrocarbon fields results from the identification of the reservoirs, the seals, and the 
traps where petroleum accumulated. This article will show that western Greece has important petroleum systems as indicated by surface geology, the relatively few boreholes, and seismic data, and that these systems are also active in the Ionian Sea. The possible traps proposed here need verification, predominantly by modern seismic data acquisition. Additionally, this article shows that the Ionian zone contains both oil shale and shale gas reservoirs that can be unconventionally explored.

\section{GEOLOGIC SETTING}

Western Greece is dominated by the external zones of the Hellenide fold-and-thrust belt, namely the pre-Apulian (or Paxos), Ionian, and Gavrovo zones (Figure 1B). From the Triassic to the Late Cretaceous, western Greece was part of the Apulian continental block on the southern passive margin of the Tethys Ocean (Figure 1A). In this area, siliceous facies are widely associated with organic carbon-rich deposits. Pre-Apulian zone rocks consist of Triassic to Miocene deposits, mostly mixed neritic-pelagic carbonates. Hydrocarbon source rocks include pelagic deposits rich in marine organic material, although terrigenous organic matter is also found in siliciclastic sediments (Rigakis et al., 2004; Karakitsios and Rigakis, 2007). The Ionian zone consists of sedimentary rocks ranging from Triassic evaporites to Jurassic-upper Eocene carbonates and minor cherts and shales, overlain by Oligocene flysch. Organic-rich intervals occur within Triassic evaporites and Jurassic-Cretaceous pelagic argillaceous sediments (Karakitsios, 1995; Karakitsios and Rigakis, 1996, 2007; Rigakis and Karakitsios, 1998). The Gavrovo zone was a shallowwater platform from the Triassic to the late Eocene, from which no organic matter-rich deposits have so far been found (Karakitsios and Rigakis, 2007).

At a regional scale (hundreds of kilometers), the Alpine belt can be considered as the margin of the Tethys Ocean, inverted by the collision of the Apulian block with Europe (de Graciansky et al., 1989). On a smaller scale (tens of kilometers), in the Hellenic realm, the subbasins of the Tethyan margin have been inverted to produce the main thrust sheets or folded zones, known as Hellenides. This occurred progressively from the innermost (eastern) zones to the more external (western) zones (Karakitsios, 1995).

The thrust boundary between the Ionian and pre-Apulian zones is marked by intrusive evaporites. This suggests that contractional deformation was the most important structural control on orogenesis in western Greece. Although halokinesis was important along boundary faults during the Mesozoic extension, thrusting has overprinted the Mesozoic extensional structures to such an extent that the latter are almost impossible to distinguish (Karakitsios and Rigakis, 2007). Field observations of the relationship between the pre-Apulian and Ionian zones emphasize the close association between Hellenide thrusts and folds and areas of evaporite exposure (evaporite dissolution-collapse breccias; Karakitsios and Pomoni-Papaioannou, 1998; Pomoni-Papaioannou et al., 2004), even where the precise location of the thrust is unclear. Evaporites outcrop along the leading edges of thrust sheets in both zones. Their location, together with their occurrence in tectonic windows above tectonized flysch (observed in many localities), suggests that the evaporites represent the lowest detachment level of individual overthrust sheets in the external Hellenides. Furthermore, the absence of subevaporite units from outcrops in western Greece, the great thickness of the evaporites ( $>3 \mathrm{~km}$ [ $2 \mathrm{mi}$ ] in boreholes in the Ionian zone; IGRS-IFP, 1966; BP, 1971), and the probable incorporation of Permian basement into the thin-skinned orogenic wedge east of the Pindos thrust (Smith and Moores, 1974) all support the idea that the evaporites form a moderate to major décollement level throughout the external Hellenides, instead of a widespread diapirism (Underhill, 1988; Karakitsios, 1992, 1995; Kamberis et al., 1996; Karakitsios and Rigakis, 2007). Thus, the function of the evaporites is similar to that which is well known in thin-skinned thrust belts in western Europe (Rigassi, 1977; Laubscher, 1978; Williams, 1985; Allen et al., 1986; Ricci Lucchi, 1986). 


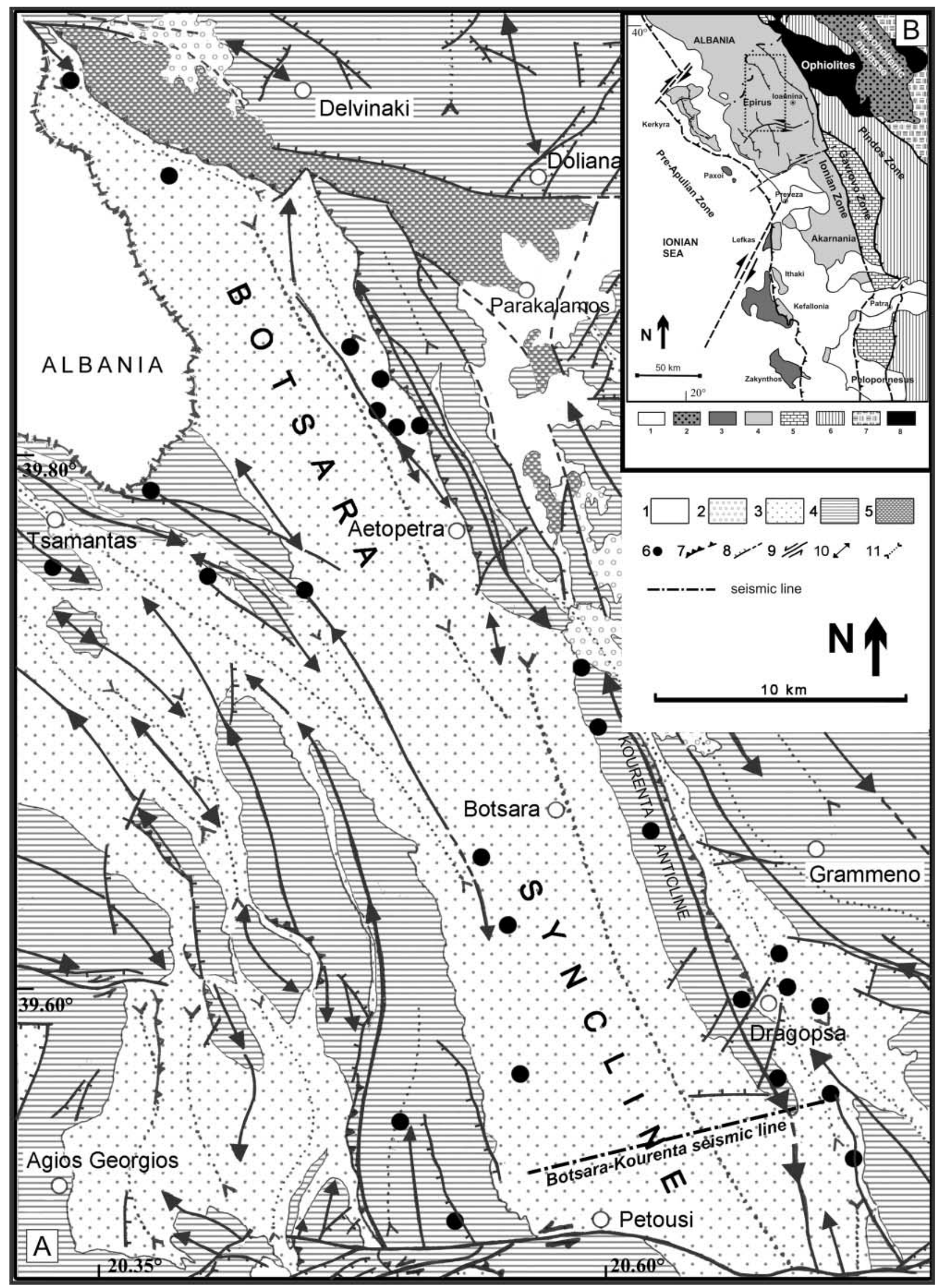




\section{Ionian Zone}

The Ionian zone is made up of three distinct stratigraphic sequences (Karakitsios, 1992, 1995; Figure 3):

The prerift sequence represented by the Lower Jurassic (Hettangian to Sinemurian) Pantokrator limestones. These shallow-water limestones overlie Lower to Middle Triassic evaporites ( $>2000 \mathrm{~m}$ [6562 ft] thick) and the Foustapidima limestones of the Ladinian-Rhaetian. The subevaporitic basement of the Ionian zone is not exposed at the surface, nor has it been penetrated by deep wells.

The overlying synrift sequence begins with the Pliensbachian pelagic Siniais limestones and their lateral equivalent hemipelagic Louros limestones. These formations correspond to the general deepening of the Ionian domain with the formation of the Ionian Basin. The structural differentiation that followed separated the initial basin into smaller paleogeographic units with a half-graben geometry. This is recorded in the abruptly changing thickness of the synrift formations that take the form of synsedimentary wedges. In the deeper parts of the half grabens, these wedges include complete ToarcianTithonian successions, whereas in the elevated parts of the half grabens; the succession is interrupted by unconformities. The directions of synsedimentary structures (e.g., slumps and synsedimentary faults) indicate that deposition was controlled both by structures formed during extension related to the opening of the Neotethys Ocean and by halokinesis of evaporites at the base of the Ionian zone succession (Karakitsios, 1995; Figure 4).

The postrift sequence begins with the pelagic Vigla limestones, whose deposition was synchronous throughout the Ionian Basin, beginning in the early Berriasian (Karakitsios, 1992; Karakitsios and Koletti, 1992). The Vigla limestones blanket the synrift structures (Karakitsios, 1992) and, in some cases, directly overlie prerift units (e.g., the Pantokrator limestones). The base of the Vigla limestones represents the breakup unconformity of the postrift sequence in the Ionian Basin. Longstanding differential subsidence during the deposition of the Vigla limestones, as shown by the marked variations in the thickness of this formation, was probably caused by continued halokinesis of the basal Ionian zone evaporites.

The Senonian limestones, which rest on the Vigla limestones, correspond to calciturbidites comprising limestones with fragments of globotruncanids and rudists, and microbrecciated intervals with limestones and rudist fragments within calcareous cement containing pelagic fauna. The facies distribution of the Senonian reflects the separation of the Ionian Basin into a central, topographically higher area characterized by reduced sedimentation, and two surrounding talus slopes with increased sedimentation (IGRSIFP, 1966). Adjacent to this area, separate carbonate platforms (the Gavrovo platform to the east and the Apulian platform to the west), provided the clastic carbonate material that was transported by turbidity currents into the Ionian Basin.

Homogenous Paleocene and Eocene sediments were deposited without significant facies changes. During the Paleocene, the erosion of Cretaceous carbonates on the Gavrovo and Apulian platforms provided the Ionian Basin with brecciated rock fragments. However, the supply of clastic material diminished significantly during the Eocene, especially in the central Ionian Basin. The main depositional facies during this period were platy wackestone and mudstone with Globigerinidae and siliceous nodules, analogous to those of the Vigla limestones, but lack continuous cherty intervals. The greatest thicknesses of the Eocene units can be found in the marginal parts of the Ionian zone, where the microbreccias are more frequent.

Flysch sedimentation in the main part of the Ionian zone began at the Eocene-Oligocene boundary and is deposited by some marly limestone transitional beds conformable overlying the upper Eocene limestones (IGRS-IFP, 1966; Bellas, 1997).

Figure 2. (A) Structural map of the northwestern part of the Epirus region with the surface oil shows (see regional location in the inset map (B) (Karakitsios and Rigakis, 2007). (1) Quaternary. (2) Continental Neogene. (3) Flysch (Oligocene-Burdigalian). (4) Limestone sequence (Upper Triassic-Eocene). (5) Evaporite dissolution-collapse breccias (Triassic). (6) Surface oil show. (7) Thrust. (8) Fault. (9) Strike-slip fault. (10) Anticlinal axis. (11) Synclinal axis. Inset legend interpretations are the same as in Figure 1. The trace of the seismic line shown in Figure 9 is also indicated. 


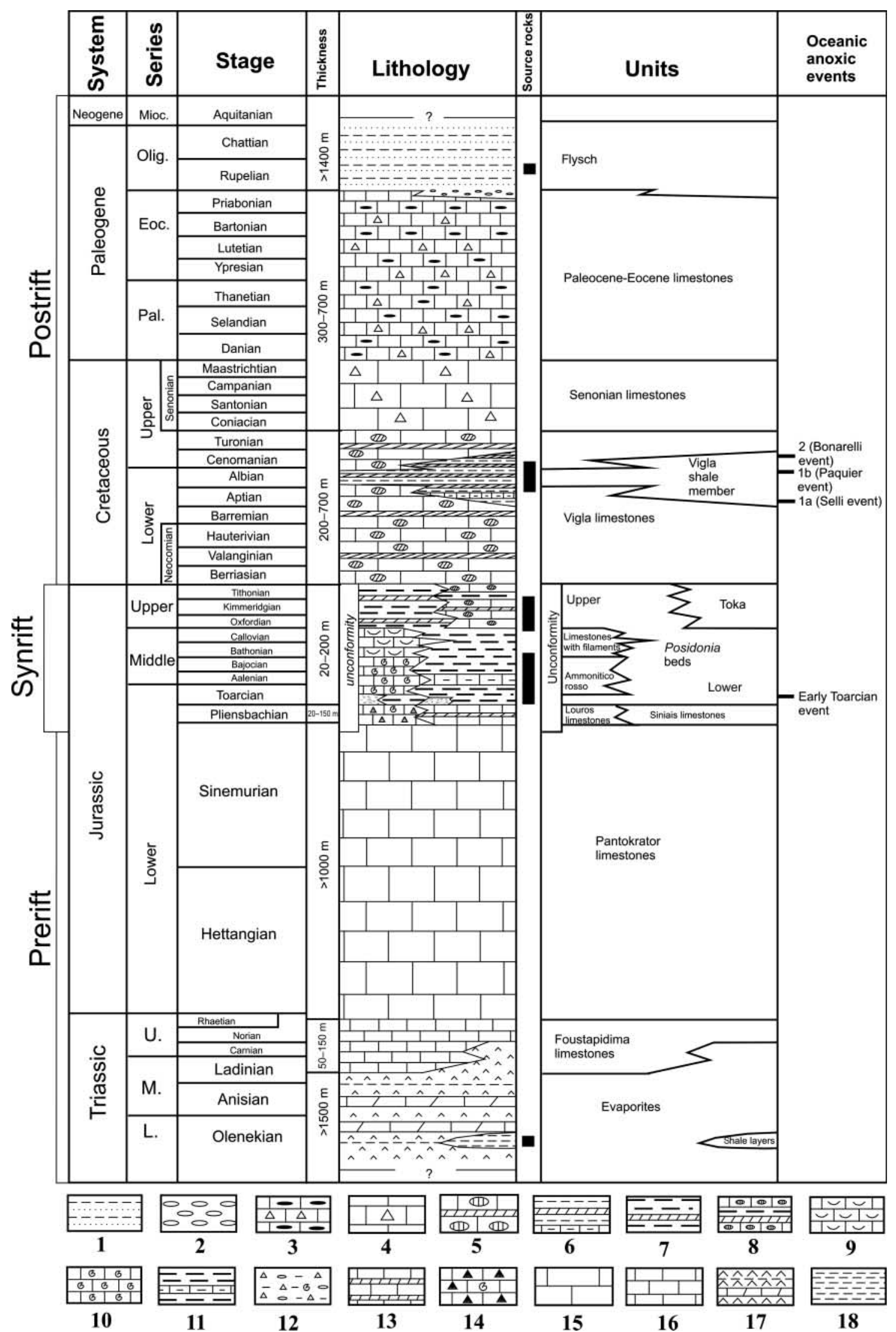



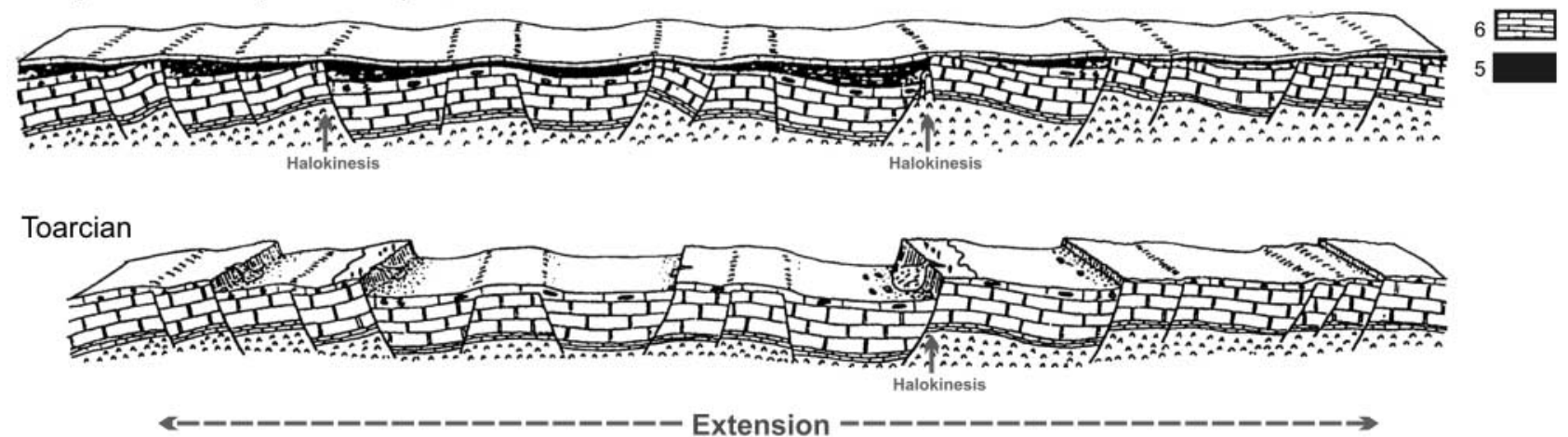

Pliensbachian

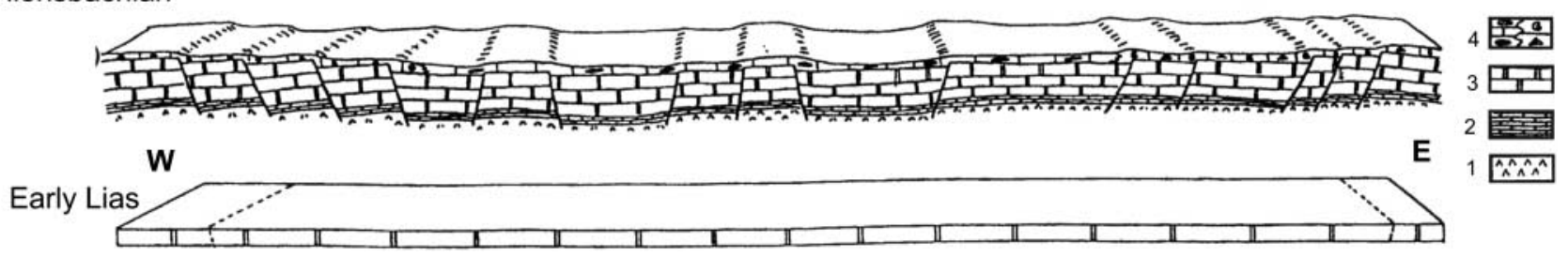

Figure 4. Paleogeographic evolution of the lonian zone, from the Early Jurassic to the Early Cretaceous (Berriasian) (Karakitsios, 1992). (1) Evaporites. (2) Foustapidima limestones. (3) Pantokrator limestones. (4) Siniais and Louros limestones. (5) Synrift formations. (6) Vigla limestones.

Major orogenic movements occurred at the end of the early Miocene (Burdigalian) (IGRS-IFP, 1966), with the inversion of the Ionian Basin succession (Karakitsios, 1995). The structures inherited from the Jurassic extensional phase were reactivated during the compressional phase of orogenesis with westward and eastward displacements. In general, extensional faults were reactivated with either reverse or strike-slip displacement, consistent with classical inversion tectonics. In some cases, during the compressional phase, extensional faults were not reactivated as thrusts in the way of classical inversion tectonics, but the elevated extensional footwalls were thrust over preexisting hanging walls by the movement of the basal evaporitic units (Karakitsios, 1995; Figure 5). This was facilitated by diapiric movements involving the basal evaporitic salt intervals. Field and available seismic data suggest that at least a moderate decollement occurred along the evaporites (Karakitsios, 1995; Kokinou et al., 2005). However, the degree of this decollement is unknown and still remains speculative. Considering the existing data on the external Hellenides, the hypothesis of a major decollement along the evaporites is more favorable. In fact, as the Ionian and Gavrovo-Tripolis crust corresponds to thinned continental crust (Makris, 1977; Bonneau, 1982; Finetti, 1982; Bassoullet et al., 1993), the subevaporitic basement of the Ionian zone is probably underthrust and incorporated into the thin-skinned orogenic wedge east of the Pindos thrust (Smith and Moores, 1974), or it has been subducted beneath the more internal zones. Thus, it has been subjected either to basement deformation east of the Ionian zone or to continental subduction. Continental subduction of the subevaporitic basement eastward of

Figure 3. Synthetic lithostratigraphic column of the lonian zone (modified from Karakitsios, 1995; used with permission of AAPG). (1) Pelites and sandstones. (2) Conglomerate. (3) Limestones with rare cherty intercalations, occasionally brecciated. (4) Pelagic limestones with calciturbidite intercalations. (5) Pelagic limestones with cherts. (6) Cherty beds with shale and marl intercalations. (7) Alternating cherty and shale bends. (8) Pelagic limestones with cherty nodules and marls. (9) Pelagic limestones with lamellibranches. (10) Pelagic, nodular red limestones with ammonites. (11) Marly limestones and laminated marls. (12) Conglomerates-breccias and marls with ammonites. (13) Pelagic limestones with rare cherty intercalations. (14) External platform limestones with brachiopods and small ammonites in the upper part. (15) Platform limestones. (16) Thin-bedded black limestones. (17) Evaporites. (18) Shale horizons. OAE = oceanic anoxic event; Mioc. = Miocene; Olig. = Oligocene; Eoc. = Eocene; Pal. = Paleocene; $\mathrm{U}=$ Upper; $\mathrm{M}=$ Middle; $\mathrm{L}=$ Lower; Malm. = Malm; Dogg. = Dogger. 
Figure 5. Examples of inversion tectonics affecting a halfgraben system with evaporitic basement (Ionian zone, northwestern Greece) (modified from Karakitsios, 1995; used with permission of AAPG). (A) Classical inversion tectonics. (B) Particular case of inversion tectonics observed at locations where the evaporitic substratum halokinesis was more expressed and, consequently, the footwalls elevation of the extensional phase were above average. Therefore, during the compressional phase, these most elevated footwalls have been thrust over the preexisting hanging walls. $\mathrm{A} 1$ and $\mathrm{B} 1$ correspond to the beginning of the postrift period. A2 and B2 correspond to the beginning of orogenesis, showing the subsequent inversion geometries.
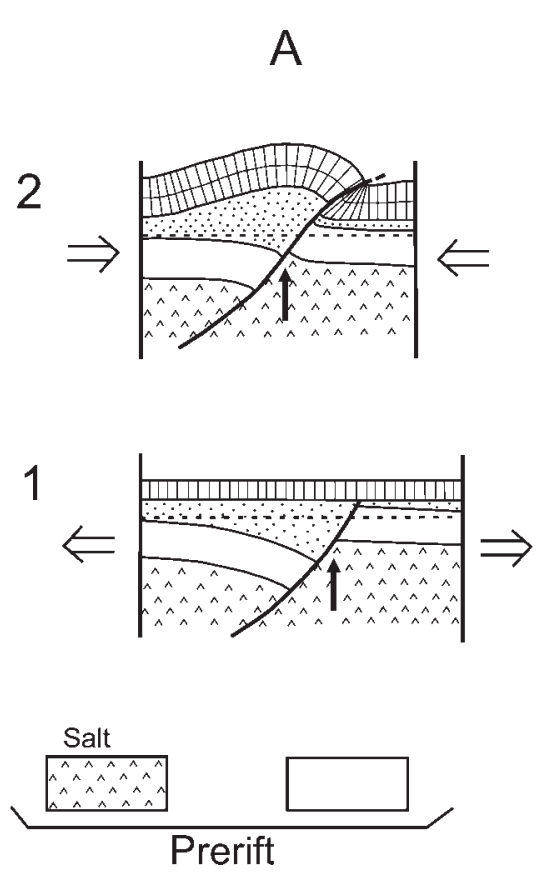
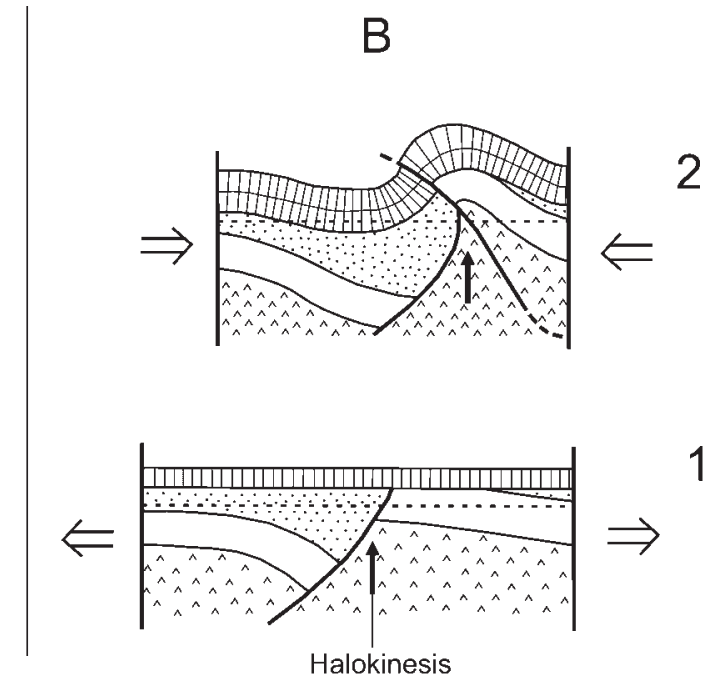

Synrift

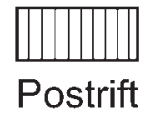

the Ionian zone is consistent with the presence of the phyllite-quartzite unit beneath the GavrovoTripolis calcareous zone in the southern Hellenides (e.g., Peloponnesus and Crete; Karakitsios and Rigakis, 2007).

\section{Pre-Apulian (Paxos) Zone}

The pre-Apulian zone corresponds to the most external domain of the fold-and-thrust belt of the Hellenides. It has traditionally been considered as a relatively uniform, Mesozoic-Cenozoic carbonate domain, transitional between the Apulian platform and the Ionian Basin. Its general setting is complex as a result of intense tectonic deformation, including phases of extension, collision, and flexural subsidence, with undetermined amounts of shortening and block rotation (Accordi et al., 1998). Outcropping successions differ in stratigraphic completeness, sedimentary development, and faunal and/or floral content.

The depositional sequence in the pre-Apulian zone (Figure 6) begins with Triassic limestones containing intercalations of black shales and anhydrites. The upper parts of this series, according to borehole data (ESSO Hellenic, 1960, personal communication), are placed within the Toarcian to Bajocian interval. The stratigraphically lowest outcrops, located in Levkas Island, consist of Lower Jurassic dolomites and Middle Jurassic cherts and bituminous shales (Bornovas, 1964; BP, 1971). The Upper JurassicLower Cretaceous succession consists of white chalky limestones with dolomite intercalations, accompanied by rare cherts and organic carbonrich black shales, containing planktonic species together with benthic foraminifera and algal species. Lower Cretaceous limestones and dolomites crop out only on the Kefallonia Island, and their facies is less pelagic than age-equivalent Ionian facies. The depositional environment throughout the Cenomanian-Turonian interval is indicated by the presence of rudist fragments, benthic foraminifera, and algal species. The CampanianMaastrichtian platy limestones gradually become chalky with thin argillaceous layers. They contain planktonic foraminifera, in addition to rudist fragments. This coexistence indicates the presence of intraplatform basins characterizing the slope between the Apulian platform and the Ionian Basin. 
Paleocene micritic limestones with planktonic foraminifera were described by BP (1971) in the pre-Apulian zone. R. Mirkou (1974, personal communication) noted that these Paleocene units sometimes rest on Santonian or Maastrichtian limestones and that neritic facies microbreccias and brecciated limestones occur at their base. This indicates intense tectonic activity that resulted in the differentiation of the pre-Apulian zone into relatively deep-water and relatively shallow (sometimes emergent) areas, which provided the brecciated material. The lower Eocene consists of pelagic limestones with marl intercalations. The upper Eocene consists of massive limestones with algae, bryozoans, corals, echinoids, and large foraminifera. Oligocene sediments were deposited in small basins (tectonic grabens) between larger or smaller emergent areas, which were locally eroded, reflecting tectonic instability that continued throughout the Oligocene. The Oligocene-lower Miocene (Aquitanian) diversification of foraminiferal assemblages suggests the presence of subsiding foreland basins, in which spectacular slumps in carbonate turbidites are observed (Karakitsios et al., 2010b). Finally, in the late early Miocene, progressive deepening occurred, flooding the former carbonate slope (Accordi et al., 1998).

The super-Oligocene pre-Apulian sediments show the progressive passage from the Ionian typical flysch to a more calcareous (age-equivalent) facies in the pre-Apulian zone (BP, 1971), indicating that they correspond to an atypical distal flysch unit. This facies is replaced in the lower part of the pre-Apulian slope (e.g., Paxos and Antipaxos Islands) by calciturbidites (Karakitsios et al., 2010b). This unit has been partially or completely eroded in the areas corresponding to the most external part of the forebulge in the Hellenide foreland basin (Karakitsios and Rigakis, 2007).

Structures developed in the pre-Apulian zone (mainly on the islands of Kefallonia and Zakynthos) may be accommodated within a simple model of continued foreland-directed migration of Hellenide (Alpine) thrusting during the late Neogene and Quaternary (Karakitsios and Rigakis, 2007). Initial activity on the Ionian thrust can be dated as early Pliocene, and the main thrusts (and some of the backthrusts) observed in the pre-Apulian zone (e.g., on the Kefallonia and Zakynthos Islands) are of late Pliocene and Pleistocene ages (F. W. Hug, 1969, personal communication; C. Nikolaou, 1986, personal communication; Underhill, 1989).

\section{Apulian Platform}

The Apulian platform, known at the southeastern end of the Italian peninsula (Figure 1A), is one of the socalled peri-Adriatic carbonate platforms (d'Argenio, 1971, 1976; Zappaterra, 1994). It belongs to the Adria microplate, which was detached from the African plate during the Mesozoic. The Apulian carbonate platform is essentially a Mesozoic paleogeographic element, which, in large part, acted as a rigid block during the Alpine (Tertiary) orogenesis. Now, it is partly buried under the Apennine thrust sheets and partly constitutes the weakly deformed foreland of both the Apennine and Dinaric-Hellenic mountain chains (Channell et al., 1979; Mostrardini and Merlini, 1986; Underhill, 1989; Picha, 1996; Bosellini et al., 1999a, b; Bosellini, 2002; Karakitsios and Rigakis, 2007).

The Hercynian basement of the Apulian platform, folded and commonly metamorphosed, is covered by Permian-Triassic continental clastics (Pieri, 1969; Flores et al., 1991; Mattavelli et al., 1993). These are followed by thick evaporitic deposits, the Burano Formation (Figure 7). From the Middle Triassic to the early Lower Jurassic, a shallow sea spread over the Burano Formation, and a carbonate platform environment prevailed. During the Early and Middle Jurassic, the rift stage evolved into ocean spreading with the inception of the central Atlantic and the Mesogea Ocean between Adria and Africa. The Adria plate probably originated during this period and hence behaved as an independent kinematic unit, in which the carbonate sedimentation persisted through the Mesozoic and even the Paleocene on a large Bahamian-type platform, whereas large block-faulted areas of the initial platform were drowned in deep water, giving way to the accumulation of pelagic deep-water carbonates and shaly episodes. The Apulian platform is one of the persistent platforms of the initial Adria microplate. Toward the Hellenic domain, the transition of 


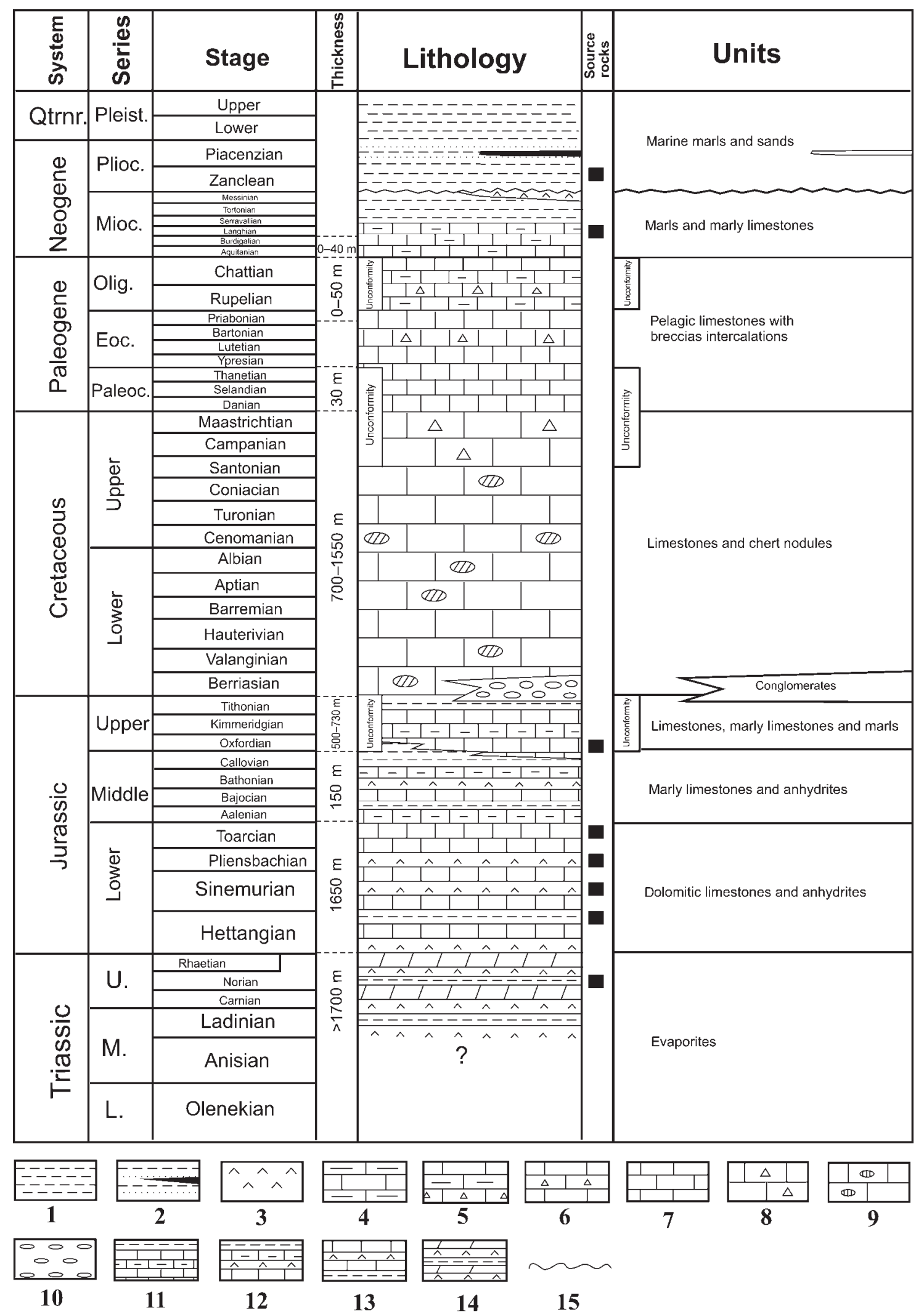


the Apulian platform to the drowned Ionian basin is recorded by the pre-Apulian zone. Also, the transition from carbonate to clastic sedimentation toward the same direction is typically diachronous, following the progressive migration of the thrust belt of the Hellenides to the Apulian foreland (to the west) together with the foredeep in front of it, as recorded by the Oligocene Ionian flysch and the super-Oligocene pre-Apulian atypical distant flysch (Karakitsios and Rigakis, 2007).

\section{PETROLEUM SYSTEMS}

\section{Source Rocks}

The main source rocks of western Greece are as follows:

1. The shale horizons in the subsurface evaporites of the Triassic Ionian and Triassic-Lower Jurassic pre-Apulian zones are known only in boreholes (IGRS-IFP 1966; Karakitsios, 1995; Karakitsios and Rigakis, 2007). The important function of Triassic formations, which are commonly associated with evaporites, in the peri-Adriatic domain as hydrocarbon source rocks (Mattavelli et al., 1993), has a particular significance in the context of the Ionian zone (Epirus region, northwestern Greece). In fact, organic-rich shale fragments have been observed in the Triassic breccias that constitute the surface expression of the subsurface Ionian evaporites (Rigakis and Karakitsios, 1998; Karakitsios and Rigakis, 2007). The Triassic breccias and associated gypsum bodies, underlining the Ionian tectonic zones, constitute diapiric injections of subsurface evaporites. They are genetically related to the subsurface evaporites, which, after their injections, have un- dergone major dissolution-collapse modifications (Karakitsios and Pomoni-Papaioannou, 1998; Pomoni-Papaioannou et al., 2004). The organicrich shale fragments in the Triassic breccias were initially deposited as stratigraphic layers in relatively shallow-water, restricted subbasins in the evaporite basin. The establishment of evaporitic sedimentation in the entire basin favored the preservation of the organic matter. The processes accounting for the formation of the evaporite collapse breccias also caused the fragmentation of the initial organic-rich layers, which now occur as organic-rich shale fragments within the Triassic breccias (Rigakis and Karakitsios, 1998; Karakitsios and Rigakis, 2007). The organic carbon content of these shale fragments indicates a very high total organic carbon (TOC) of as much as $16.12 \%$, a very good petroleum potential (PP) (8.9-98.8-mg HC/g of rock) and type I oil-prone organic matter. The Triassic shales are thermally mature; they have entered the gas window in the external and central Ionian zone, whereas in the internal Ionian zone, they have entered the oil window, as a consequence of the eastward deepening of the oil window (Karakitsios and Rigakis, 1996; Rigakis and Karakitsios, 1998). In the Paxos zone, evaporites are always found in the gas window or are overmature (Karakitsios and Rigakis, 2007).

2. The lower Posidonia beds (Toarcian) of the Ionian zone constitute the most important source rock of western Greece (Jenkyns, 1988; Baudin and Lachkar, 1990; Karakitsios, 1990, 1992, 1995; Karakitsios and Rigakis, 1996; Rigakis and Karakitsios, 1998; Karakitsios and Rigakis, 2007). These beds are composed of well-bedded pelagic laminated marls, siliceous argillites, and marly limestones, showing variations in facies and thickness (generally between 10 and $150 \mathrm{~m}$ [33 and

Figure 6. Synthetic lithostratigraphic column of the Paxos (pre-Apulian) zone (Karakitsios and Rigakis, 2007). (1) Marine marls. (2) Marine marls and sand (in black, lignite intercalations). (3) Evaporites. (4) Limestones commonly marly. (5) Pelagic limestones or marly limestones and brecciated intercalations. (6) Mixed pelagic-neritic limestones sometimes with breccias. (7) Pelagic limestones. (8) Mixed pelagic-neritic calcareous sediments with rudist fragments. (9) Pelagic limestones with nodules and rare cherty intercalations. (10) Conglomerates with calcareous and magmatic elements. (11) Pelagic limestones commonly marly. (12) Limestones, shales, and basal anhydrites. (13) Limestones and dolomitic limestones, anhydrites, and shale intercalations. (14) Evaporites with shale intercalations. (15) Unconformity. Qtrnr = Quaternary; Pleist = Pleistocene; Plioc = Pliocene; Mioc = Miocene; Olig = Oligocene; Eoc = Eocene; Paleoc = Paleocene; U = Upper; $\mathrm{M}=$ Middle; L = Lower; Malm. = Malm; Dogg. = Dogger. 
Figure 7. Type sequence of the deposits on the Adria continental margin. Age intervals are indicative; stratigraphy is correlated to the main stages of the geodynamic evolution. Triassic evaporites and subflysch hemipelagites correspond to the main detachment levels. Main source rock (SR) intervals are shown (Mattavelli et al., 1993). (1) Conglomerates. (2) Sandstones. (3) Marls. (4) Limestones. (5) Cherty limestones. (6) Evaporites. (7) Dolomites. (8) Metamorphic rocks. $\mathrm{Pl}=$ Pliocene; $\mathrm{Mi}=$ Miocene; $\mathrm{Pg}=$ Paleogene; $\mathrm{K}=$ Cretaceous; $\mathrm{J}=$ Jurassic; $\mathrm{Tr}=$ Triassic; $\mathrm{Pz}=$ Paleozoic.

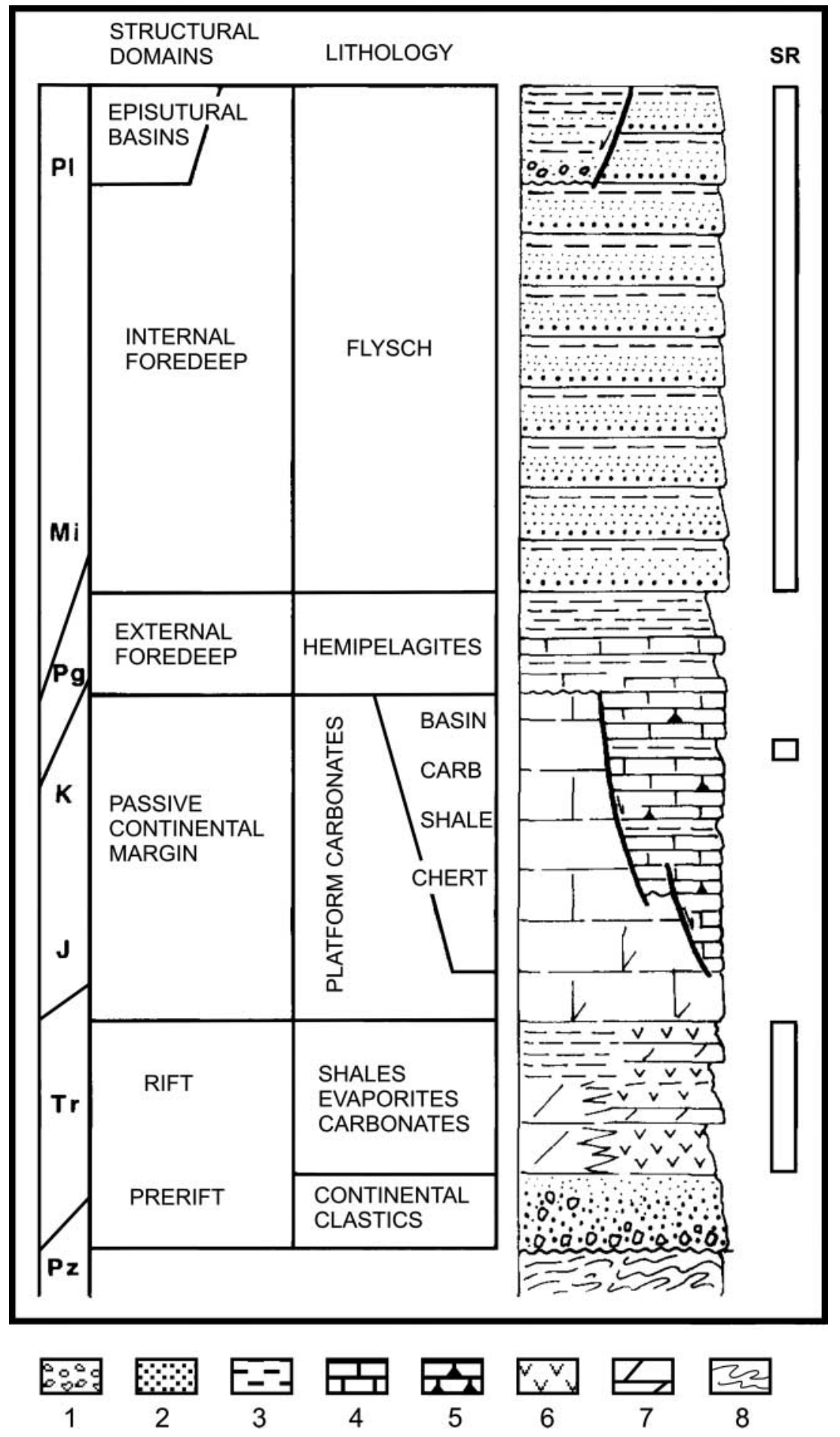

$492 \mathrm{ft}$ ]) depending on their position in each half graben (Karakitsios 1990; 1992; 1995). The Toarcian age of this formation is derived from the included ammonites and nannofossil assemblages (Karakitsios, 1990). The TOC content of lower Posidonia beds ranges from 1.05\% to $19.12 \%$ (average, $2.7 \%$ ); the organic matter is of types I to II (prone to oil generation); their $\mathrm{PP}$, between 4- and 125.85-mg HC/g of rock, and in most cases, are mature in terms of oil generation ( $\mathrm{R}_{\mathrm{o}} \%$, between 0.6 and 1.01), having entered the oil window (Karakitsios and 
Rigakis, 1996; Rigakis and Karakitsios, 1998; Karakitsios and Rigakis, 2007). The accumulation and preservation of the organic matter is directly related to the geometry of the synrift period of the Ionian basin (Figures 3, 4). The geometry of the restricted subbasins favored water stagnation and, consequently, the development of local euxinic conditions in the bottom waters (Karakitsios, 1995). The anoxia was reinforced for a smaller interval by the well-documented early Toarcian oceanic anoxic event (OAE), which has been recorded in the deposition of the most organic-rich black shales at the base of the formation (Karakitsios, 1995; Karakitsios and Rigakis, 2007; Karakitsios et al., 2010a).

3. The upper Posidonia beds of the Ionian zone consist of jasper beds with cherty clays, commonly bituminous. The cherty horizons are rich in Posidonia (Bosistra) and radiolaria of the upper Callovian to Tithonian (Karakitsios et al., 1988). These beds also show variations in facies and thickness (generally between 10 and $140 \mathrm{~m}$ [33 and $459 \mathrm{ft}$ ]) depending on its position in each half graben. The TOC content of upper Posidonia beds is between 1.05\% and 3.34\% and, in most cases, is mature in terms of oil generation (Karakitsios and Rigakis, 1996; Rigakis and Karakitsios, 1998; Karakitsios and Rigakis, 2007). In many places of the Ionian zone, the upper Posidonia beds are not clearly differentiated from the lower Posidonia beds, and the whole formation is examined as "undifferentiated Posidonia beds." In this case, the latter represent, in general, the cumulative oil potential characteristics of lower and upper Posidonia beds.

4. The Vigla shale member of the Vigla limestones Formation is marly limestone and cherty beds with shale interbedding. The Vigla shales were dated by radiolaria and globotruncanids (upper part) to Aptian-early Turonian (Karakitsios et al., 2004; Karakitsios et al., 2007a, 2007b). They are rich in TOC (between 0.94 and $5.00 \mathrm{wt}$ \%) and have a high PP (4.85-25-mg HC/g of rock). Their kerogen is of types I to II, originating from marine organisms (phytoplankton, zooplankton, and bacteria) in a reducing environment and is capable of generating mainly liquid hydrocarbons (Karakitsios and Rigakis, 1996; Rigakis and Karakitsios, 1998; Karakitsios and Rigakis, 2007). The Vigla shales, in the central and external Ionian zones, are in the early maturation stage, whereas, in the internal Ionian zone, they are mature in terms of oil generation (Rigakis and Karakitsios, 1998; Karakitsios and Rigakis, 2007). In the lower and upper parts of the Vigla shale member, three thin, isolated black shale horizons are observed, corresponding to the Selli OAEla, the Paquier OAElb with a TOC of 28.9 wt. \%, and the Cenomanian-Turonian (Bonarelli) OAE2 with a TOC of 44.5 wt. \% (Karakitsios et al., 2004; Tsikos et al., 2004; Karakitsios et al., 2007a, Karakitsios and Rigakis, 2007). The thickness of the Vigla shale member ranges between 10 and $65 \mathrm{~m}$ (33 and $213 \mathrm{ft}$ ). The accumulation and preservation of organic matter in the Vigla shale member is generally attributed to preserved subbasins because of the continuation of halokinetic movements during the postrift period (Karakitsios, 1995). The OAEs (OAEla, OAElb, and OAE2) are recorded in the thin horizons, which are very rich in organic matter. These horizons, by themselves, cannot be considered as source rocks (because of their small thickness), and cannot contribute to the oil potential of the Vigla shale source rocks (Karakitsios et al., 2007a, 2010a).

5. Immature organic matter of mixed marineterrestrial origin observed in the upper Oligocenelower or middle Miocene continental slope system of Diapondia Islands (northwestern Ionian zone) may be mature in the downslope equivalent deep-sea mudstone facies, where sedimentary overburden is probably sufficient to reach the beginning of the oil window (Maravelis et al., in press).

The timing of maturation of the principal oilsource rocks, as it is provided from the maturityversus-time model (Rigakis and Karakitsios, 1998; Karakitsios and Rigakis, 2007), is as follows: Triassic shales entered the oil window in the Late Jurassic, the lower Posidonia beds entered in the Serravalian, and the Vigla shale member in the internal Ionian 
zone entered the oil window after the Serravalian. It is important that, in the two last cases, maturity occurred after the Ionian zone orogenesis (Burdigalian) and the subsequent formation of the trap structures.

In the pre-Apulian (Paxos) zone, extending mostly offshore, apart from its previously mentioned basal evaporites, good source rocks are as follows:

1. The Lower Jurassic with four horizons have fair organic matter (TOC, average, 0.6 wt. \%; PP, average, $1 \mathrm{mg} / \mathrm{g}$ ) and a types II to III organic matter. The Paxi-Gaios-1x well showed that the oil window is at 1850 to $3250 \mathrm{~m}(6070-10,663 \mathrm{ft})$ and that the Upper Jurassic rocks are mature (Rigakis et al., 2004; Karakitsios and Rigakis, 2007).

2. The Upper Jurassic marly limestones are the best source rocks of this zone. They are more than $200 \mathrm{~m}$ (656 ft) thick, have a TOC ranging between 0.6 and 11.2 wt. \% (average, 2.2 wt. \%), and organic matter of types I to II, highly oil prone. The average PP values are $11 \mathrm{mg} / \mathrm{g}$, with a maximum value of $43.5 \mathrm{mg} / \mathrm{g}$. These characteristics confirm that Upper Jurassic source rocks can produce significant quantities of oil (Rigakis et al., 2004; Karakitsios and Rigakis, 2007). In the Paxi-Gaios-1x well, the Upper Jurassic rocks are immature, but the general structure of this zone shows that, in other places, they are positioned at greater depths, corresponding to the oil window (1850-3260 m [6070$10,696 \mathrm{ft}]$ ), and are mature.

3. The Miocene and Pliocene source rock horizons are of less importance. Horizons rich in organic carbon, with type III (gas prone) immature organic matter are hosted in the Miocene marls (e.g., Tortonian marls of Zakynthos Island), whereas lignitic horizons rich in organic carbon, with type III immature organic matter (capable of gas generation), were identified in Pliocene clastic sediments (Rigakis et al., 2004; Karakitsios and Rigakis, 2007).

4. The eastern part of the Greek Ionian Sea belongs to the pre-Apulian zone, whereas the western part, to the Apulian platform. Hydrocarbon source rocks of the Apulian platform are mainly the organic-rich sediments into the Triassic Burano evaporites (Mattavelli and Novelli, 1990; Mattavelli et al., 1993). Generally, in the periAdriatic area, most of the major hydrocarbon concentrations originate from source rocks occurring in Triassic formations (commonly associated with evaporites) that were deposited in intracontinental basins (Bosellini and Hsü, 1973; Pieri and Mattavelli, 1986; Zappaterra, 1994). Additionally, much of the petroleum of Albania comes from Triassic limestones (Mattavelli and Novelli, 1990; Zappaterra, 1994). In the Greek submarine part of the Apulian platform, except for its Triassic evaporites, other contributing source rocks are those of the pre-Apulian (Paxos) zone. The migration of the latter may lead to hydrocarbon accumulations in the big offshore Apulian platform anticlines of large radius of curvature.

Maturity-versus-time modeling of the oil generation interval for the principal pre-Apulian source rocks (Karakitsios and Rigakis, 2007) provides the following estimates: Triassic source rocks became mature in the Middle Jurassic; Lower Jurassic source rocks became mature in the Late Jurassic; and maturation of Upper Jurassic source rocks occurred in the early Oligocene. Oil generation from Triassic and Lower Jurassic rocks in the pre-Apulian zone occurred before major orogenesis. In the deeper parts of the Upper Jurassic source rocks, oil generation occurred before the main orogenesis, whereas for the shallower ones, much later (6 Ma). However, rates of oil generation are generally low, and more oil could have been generated from these source rocks after orogenesis and trap formation (Karakitsios and Rigakis, 2007).

\section{Reservoirs}

Reservoir rocks in western Greece are located in several levels within the Mesozoic-Paleogene calcareous sequence of the Ionian zone, such as the Pantokrator limestones, or the Senonian and the Paleocene-Eocene limestones (Karakitsios and Rigakis, 2007). The well-known upper Senonian calcareous breccias of the Ionian zone (Aubouin, 1959) correspond to calciturbidites of different 
lithologies grading from fine- to coarse-grained sequences intercalated with debris-flow deposits and thick slumped levels. The upper Senonian calciturbidites constitute an important reservoir in which no particular attention has been given so far. The calciturbidite sequence extends commonly into the Paleocene-Eocene limestones of the Ionian zone. Indeed, the porosity level sometimes reaches 8\% in the Upper Cretaceous-Eocene formations. The West Katakolo (northwestern Peloponnesus) oil field (Figure 8) is a marginal field that contains significant amounts of hydrocarbons in reservoirs of this age (Marnelis et al., 2007). In Albania, the sedimentology of the Ionian zone, Upper Cretaceous calciturbidite system was recently studied in detail by Rubert et al. (2012).

In the pre-Apulian zone, the thick Upper Cretaceous chalk sequence recognized on the Zakynthos Island is characterized by very high porosity and presents very good potential as a hydrocarbon reservoir. Additionally, several stratigraphic levels with calciturbidite deposits may be considered as good reservoirs, for example, lower Oligocene calciturbidites on the Paxos and Antipaxos Islands (Karakitsios et al., 2010b).

Additionally, porosity is generally much higher in the tectonic zones of western Greece, where the extensive faulting has created long fracture zones, thus greatly increasing secondary porosity and permeability.

Finally, on the Apulian platform, the reservoir rocks belong to older-than-Pliocene carbonate platform formations, unaffected or only slightly affected by compressional tectonics. Additionally, reservoirs are included in the undeformed or slightly deformed clastic Pliocene sediments (Mattavelli et al., 1993).

\section{Seals and Traps}

The Ionian zone Oligocene flysch constitutes the main seal, trapping the hydrocarbon concentrations within the calcareous series. Also, the upper Miocene and Pliocene marls form excellent seal rocks in western Greece, as seen through the West Katakolo field. The best caprock formation is the Triassic evaporites for the traps existing beneath the thrust units (subthrust plays). In addition, under specific conditions, such as the bed thickness and structure, the source rocks themselves may sometimes act as seals. Indeed, the Posidonia shales, which exhibit substantial thickness, when uplifted as an anticline before or during their maturation, may trap below them oil that has migrated per desensum from them (Figure 9) or per ascensum from shales of the Triassic evaporites.

Concerning the Ionian flysch, most Ionian surface anticlines form topographic highs, which have been extensively eroded, and whatever hydrocarbon accumulation that might have been trapped in these structures is no longer present, explaining the absence of surface oil shows at the top of the anticlines (with the rare exception of oil shows derived by migrations of active oil generation). Conversely, surface synclines, which are topographic lows, escaped erosion and retained the flysch cover. Indeed, major synclines in the Ionian realm (such as the Botsara syncline; Figures 2, 9) include a series of minor anticlines, which, in themselves, form hydrocarbon traps. A different category of potential trapping structures contains the Epirus-Akarnania syncline (Figure 8), which, because of its wider geographic extent, as well as the lateral transition between the Ionian zone and the adjacent Gavrovo zone, is expected to contain many more and larger anticlinal structures in relation to those of the Botsara syncline.

The influence of the Triassic evaporites in the evolution of the Ionian basin is of the utmost importance; the Jurassic extensional phase triggered halokinesis of the basement evaporites. This affected the synrift mechanism by enhancing the extensional fault throws, resulting in the formation of small, structurally controlled subbasins with half-graben geometry (Karakitsios, 1992, 1995). These restricted subbasins favored water stagnation creating the local euxinic conditions of the bottom waters, which are necessary for the preservation of organic material. During the compressional orogenetic phase, preexisting extensional structures (Pliensbachian to Tithonian) were reactivated. The precise geometric characteristics of inverted basins depend on the intensity of evaporitic halokinesis and on the lithologic properties of the evaporites, as well as on diapiric intrusions in the Ionian Alpine tectonic zones and 


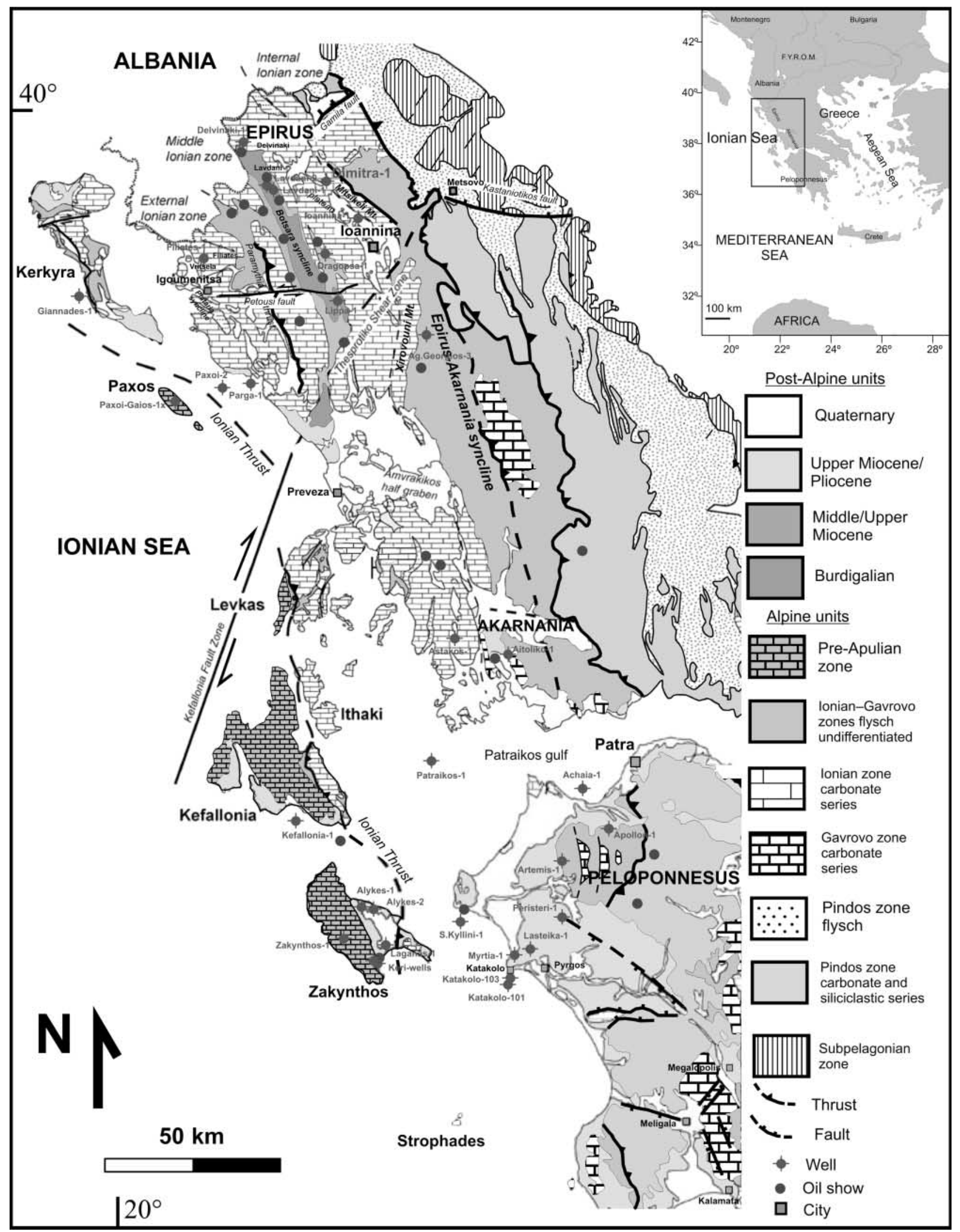



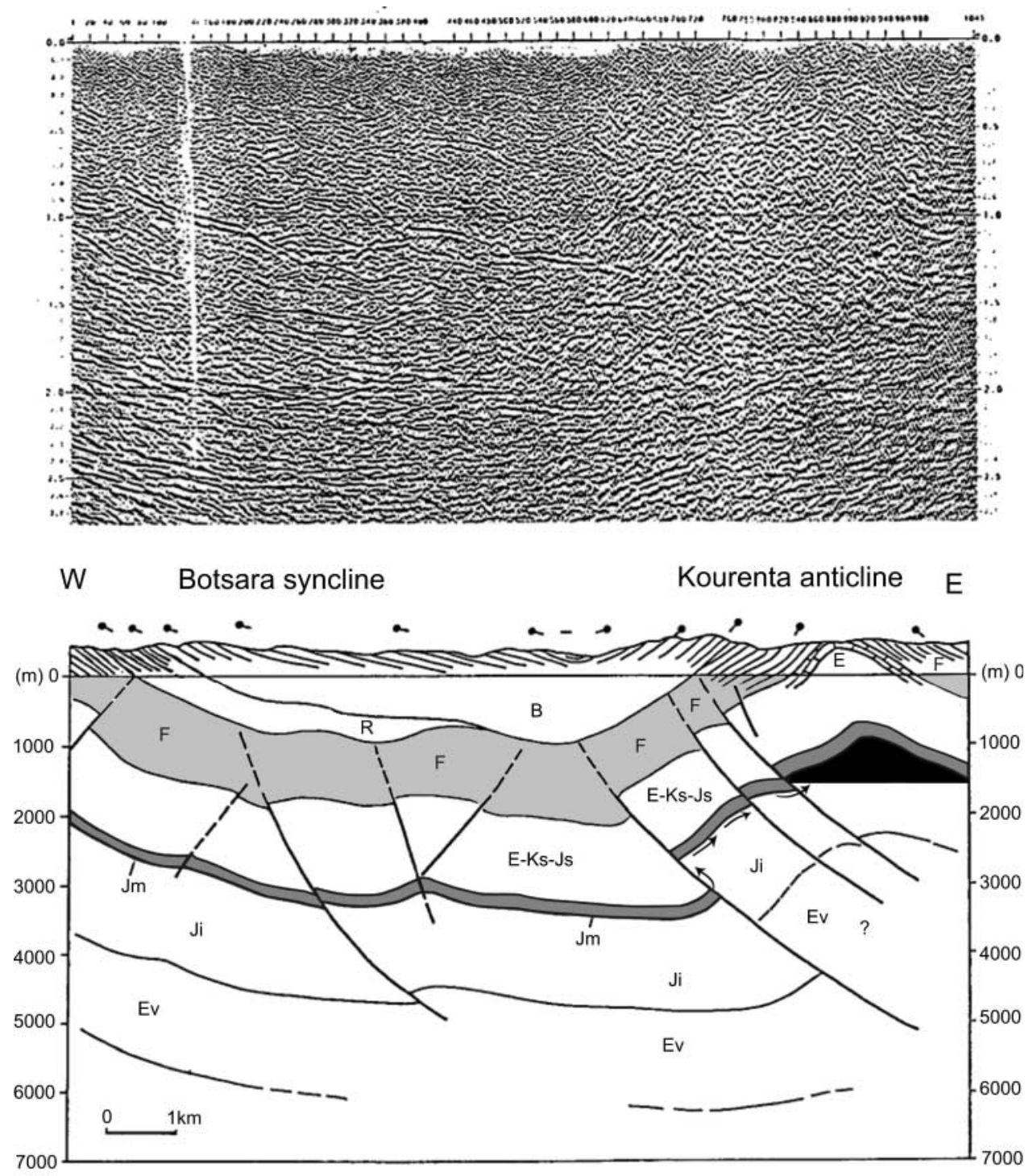

Jm: Middle Jurassic

Ji: Lower Jurassic

Ev: Evaporites (Triassic)

Possible oil accumulation

a Dip of strata
Figure 9. Geologic section (bottom) resulting from the interpretation of the seismic profile (top), and possible oil accumulation (modified from Marnelis et al., 2007). The location of the seismic line is noted in Figure 2. transc. = transcurrent fault.
B: Burdigalian
F: Oligocene flysch
E-Ks-Js: Upper Jurassic-Eocene oil migration

sult is the tectonic duplication of the Ionian series, which favors hydrocarbon trapping within the lower carbonate series (subthrust plays); the thrusts are

Figure 8. Geologic map of western Greece, indicating the Alpine zones with their flysch, the post-Alpine deposits, the well, and the principal oil show locations. In Peloponnesus, the Pindos zone is not differentiated from its flysch. Borehole operators are as follows: Delvinaki-1, Lavdani-1, Lavdani-2, Dragopsa-1, Giannades-1, Lippa-1, Ag. Georgios-3, Patraikos-1, and Achaia-1 by the Public Petroleum Corporation (DEP); Dimitra-1, Apollon-1, and Artemis-1 by Enterprise Oil; Ioannina-1 by the General Exploration and Exploitation S.A.; Filiates-1, Astakos-1, and Zakynthos-1 by ESSO Hellenic; Parga-1 and Paxoi-2 by Azienda Generale Italiana Petroll (AGIP); Aitoliko-1 by British Petroleum Co.; Kefallonia-1 by Pan-Israel; Alykes-1 and Alykes-2 by London Oil Development and ESSO Hellenic; Laganas-1 by Ancar-Oil Co.; Keri-wells by Pan-Israel, Hellis, and Deilmanllio; Peristeri-1, Lasteika-1, S. Kyllini-1, Myrtia-1, Paxoi-Gaios-1x, Katakolo-103, and Katakolo-101 by the Public Petroleum Corporation and Exploitation of Hydrocarbons (DEP-EKY). 
A

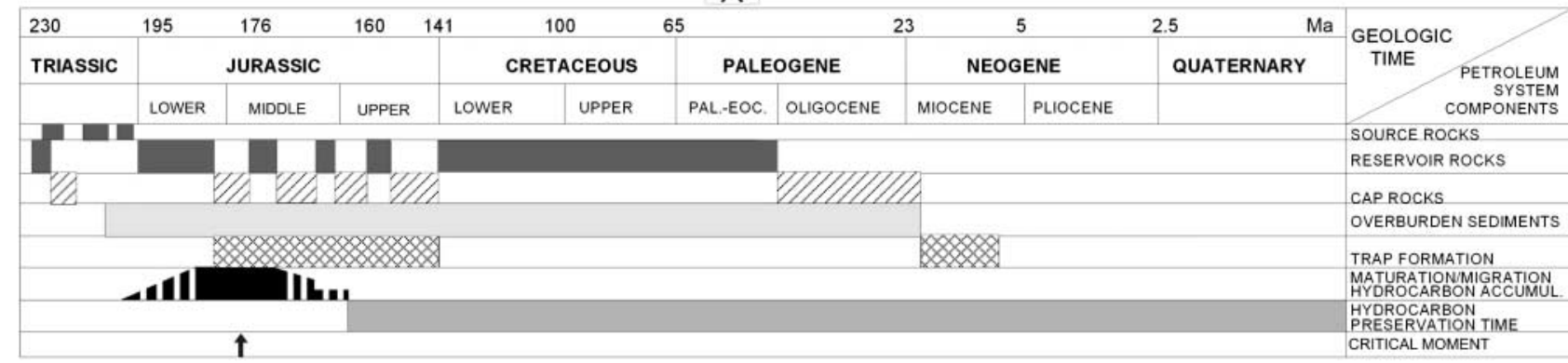

B

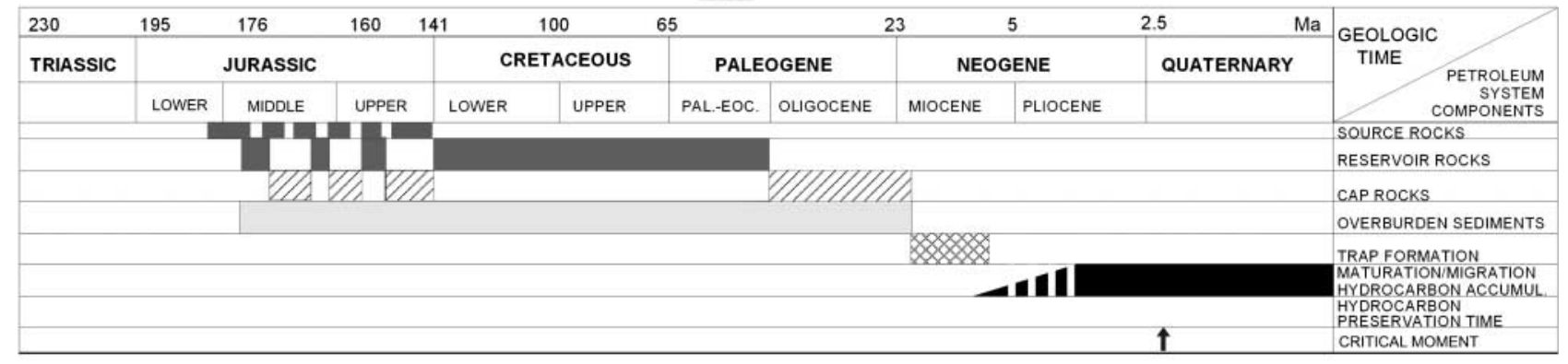

C

\begin{tabular}{|c|c|c|c|c|c|c|c|c|c|c|c|}
\hline 230 & 195 & 176 & 160 & 141 & & 65 & & & 5 & 2.5 & $-G$ \\
\hline TRIASSIC & & URASSIC & & & CEOUS & PALE & OGENE & NE & ENE & QUATERNARY & \\
\hline & LOWER & MIDDLE & UPPER & LOWER & UPPER & PAL.EOC, & OLIGOCENE & MIOCENE & PLIOCENE & & $\begin{array}{r}\text { SYSTEM } \\
\text { COMPONENTS }\end{array}$ \\
\hline & & & & & & & & & & & SOURCE ROCKS \\
\hline & & & & & & & & & & & RESERVOIR ROCKS \\
\hline & & & & & & & & & & & CAPROCKS \\
\hline & & & & & & & & & & & OVERBURDEN SEDIMENTS \\
\hline & & & & & & & & & & & $\begin{array}{l}\text { TRAP FORMATION } \\
\text { MATURATIONIMIGRATION } \\
\text { HYDROCARBON ACCUMUL. } \\
\text { HYDROCARBON } \\
\text { PRESERVATION TIME }\end{array}$ \\
\hline & & & & & & & & & & & CRITICAL MOMENT \\
\hline
\end{tabular}

Figure 10. The lonian zone petroleum systems. (A) Petroleum system related to Triassic source rocks. (B) Petroleum system related to Jurassic source rocks. (C) Petroleum system related to Cretaceous source rocks. Critical moment refers to "...the point in time selected by the investigator that best depicts the generation-migration-accumulation of most hydrocarbons in a petroleum system." (Magoon, 1994, p. 11).

covered by the evaporite intrusions and the flysch remnants of the lower tectonic unit. Such traps may contain significant hydrocarbon accumulations.

The presented cases are also considered promising because trap formation occurred prior to or during the organic matter maturity in most Ionian source rocks. The identification of these traps requires the combination of surface geology and modern seismic reflection profiling.

The petroleum systems of the Ionian zone are summarized in Figure 10.

The most significant seal formations in the preApulian zone are the Triassic-Lower Jurassic evaporites along with the Messinian evaporites and the flysch-type clastic Miocene and Pliocene series.
Messinian evaporites seal the major anticlines characterizing the pre-Apulian zone, creating very promising hydrocarbon trapping possibilities.

The degree of participation of the subevaporitic base in the deformation of the sedimentary cover, in Ionian as well as the pre-Apulian zones, determines the position and magnitude of the traps in the unknown (deeper than the evaporites) Paleozoic formations, for which little information is available regarding the petroleum reservoir or source rocks.

In the Apulian platform, the seal formations (caprock) mainly belong to the undeformed or slightly deformed clastic Pliocene sediments, which are unconformably deposited on the foreland margin. Additionally, seals are found in the sub-Pliocene 
sequence, which is unaffected or only slightly affected by compressional tectonics (Mattavelli et al., 1993).

\section{PETROLEUM POTENTIAL AREAS IN WESTERN GREECE}

The overoptimism with regard to hydrocarbon discoveries in western Greece should hardly be considered the correct scientific approach. Systematic exploration in this area should immediately commence once more, before any significant conclusion can be reached. After a long hiatus in exploration activity in this area, following the gradual privatization of the state oil company (Public Petroleum Corporation of Greece), which resulted in the absence of any state organization responsible for assigning and conducting petroleum research in the country, the recent creation of the Hellenic Hydrocarbon Research Management S.A. may be considered a good beginning.

The above-analyzed geologic data pinpoint certain more promising areas for hydrocarbon research in western Greece. These include land as well as offshore sites in western Greece.

\section{Onshore Sites}

The Botsara syncline is located 20 to $25 \mathrm{~km}$ (12$20 \mathrm{mi}$ ) west of Ioannina City (Figures 2, 9), with a surface extent of approximately $300 \mathrm{~km}^{2}$ $\left(116 \mathrm{mi}^{2}\right)$. This syncline contains verified mature oil source rocks as well as many surface oil shows at its edges. The rich surface data, despite the existence of few seismic profiles, show that the general syncline structure is transformed to an anticline toward the east (Kourenta anticline), covered by the flysch. The Botsara syncline is a very promising area for further seismic studies. Drilling so far has been extremely sparse, although it is generally accepted that, even in productive oil sites worldwide, only one of every ten wildcat wells produces oil, whereas the rest remain barren. Consequently, the Botsara syncline should be a primary target area for further exploration in Greece.
The Epirus syncline, east of the Mitsikeli and Xirovouni Mountains, which crosses to the south the Akarnania syncline (Figures 8, 11), has all the characteristics for trapping exploitable amounts of hydrocarbons. Vigla shale source rocks have been verified as mature and as well as most of the Posidonian shales found deeper. The general syncline structure hides any major anticlines. In addition, below the flysch cover, Ionian series limestones pass laterally into Gavrovo zone limestones (platform carbonates, deposited in a high-energy intertidal environment), whose porosity and permeability are significantly higher. As a result, large quantities of hydrocarbons produced in the Ionian zone have migrated and accumulated in the Gavrovo calcareous series (Figure 11). The surface extent of the syncline in Epirus reaches more than $500 \mathrm{~km}^{2}$ (193 $\mathrm{mi}^{2}$ ), and added to that of the Akarnania syncline, the total area is more than $2000 \mathrm{~km}^{2}$ $\left(772 \mathrm{mi}^{2}\right.$ ) (Figure 8). The area covered by the Epirus syncline, where the most encouraging data exist, ought to be the subject of systematic exploration activities.

Many anticline structures in Epirus, where evaporitic intrusions are observed, should also be explored further with modern seismic technology, for the possibility of anticline structures hidden beneath the flysch and the subsurface evaporites, at the levels of the major underground thrust zones characterizing the Ionian zone, such as the Filiates-Vritsela area, the Igoumenitsa-Plataria area, and the DelvinakiLavdani area near the Albanian border (Figure 8). These major underground thrust zones would favor the possibility of subthrust plays, in places where the Ionian sequence is repeated (compressional duplex structures). An important direct evidence that the Ionian zone is duplicated, and/or extensively thrust over the pre-Apulian zone, was found in the Filiates-1 well of $3828 \mathrm{~m}(122,559 \mathrm{ft})$ total depth (Figures 8, 11). Upper Miocene (Tortonian) marls were found during drilling at a depth of $3800 \mathrm{~m}$ $(12,467 \mathrm{ft})$ beneath 3500-m (11,483-ft)-thick Triassic evaporites to the bottom of the hole (ESSO Hellenic, 1960, personal communication).

The well Dimitra-l (Mavromatidis and Kelessidis, 2009 ) is north of the city of Ioannina (Figures 8,11 ). The well was on a subevaporite high, with ambiguity 


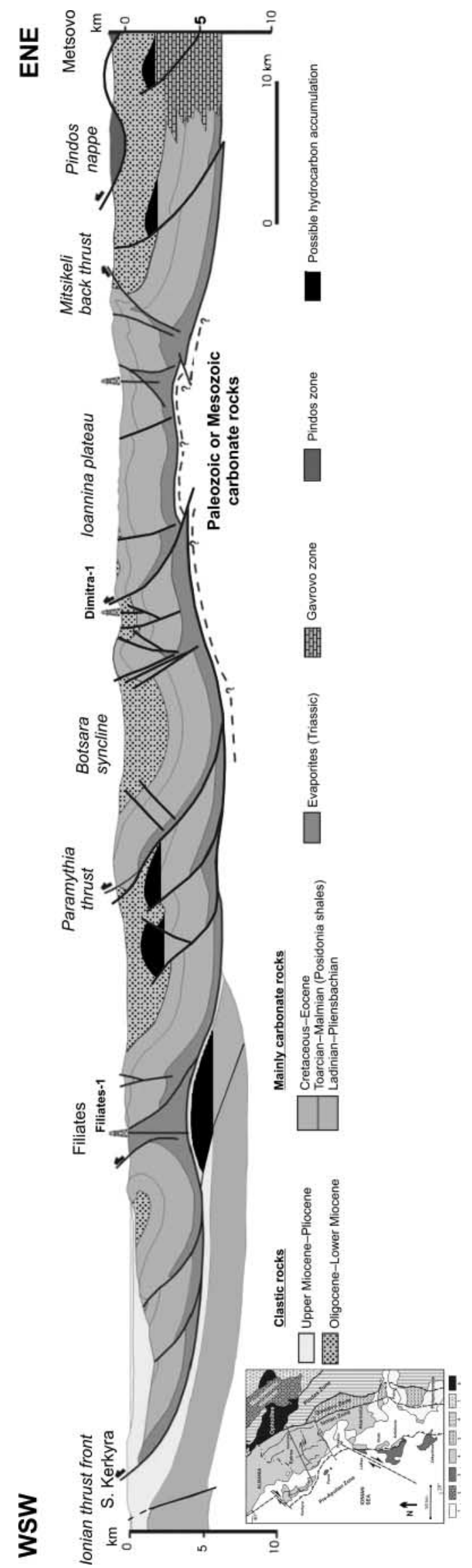

as to the nature of the stratigraphic interval beneath the Triassic evaporites. The hydrocarbon play system depended on the geologic model envisaged. The most likely model comprised a carbonate reservoir of Cretaceous-Eocene age, sealed by the Oligocene-Miocene flysch and overthrust by Triassic evaporites. The reservoir was thought to be sourced from underlying Mesozoic rocks. The alternative, less likely, model consisted of a Permian-Triassic carbonate-dominated reservoir, sealed by Triassic evaporites and probably sourced by Triassic intervals. During drilling at a depth of approximately $3900 \mathrm{~m}(12,795 \mathrm{ft})$ in the evaporitic units, high pressures were encountered, creating significant problems, and the well was killed. The well was then sidetracked at a shallower depth ( $2900 \mathrm{~m}[9514 \mathrm{ft}])$, but at approximately $3600 \mathrm{~m}$ $(11,811 \mathrm{ft})$, high formation pressures were encountered again. The well was found flowing and, finally, it was shut, plugged, and abandoned. This target remains an attractive subject for investigation.

The Preveza Basin (Figure 8), where the great thickness of the Pleistocene sediments unconformably overlies the Miocene, most probably contains gas fields as do the equivalent rocks in the eastern Durres Basin of Albania (Zelilidis et al., 2003).

The Artemis-1 and Apollon-1 wells, drilled by Enterprise Oil (Figure 8), did not reach their initial target. In the Artemis-1 well, the general structure was a faulted anticline, composed of Upper Cretaceous-Eocene fractured Ionian limestones (which are known to comprise reservoir rocks in the oil fields of Albania and offshore Adriatic Sea) capped by flysch. Some oil shows were reported, and the well was plugged and abandoned at 2375-m (7792-ft) total depth. In the Apollon-1 well, the main structure was also a faulted anticline. The well penetrated Gavrovo zone platform carbonates and flysch. The drilling target was represented by karstified platform carbonates, which have already been proven to be productive in southern Italy and the Adriatic Sea area. The well was plugged and abandoned at $1710-\mathrm{m}(5610-\mathrm{ft})$ total depth. The breach of initial agreement resulted to the withdrawal of the involved company. The drilling target of two wells remains an attractive subject for investigation. 


\section{Offshore Sites}

The offshore marginal West Katakolo oil field is the only one that has been discovered so far during the limited exploration in western Greece (Figure 8). Two wells were drilled to the Mesozoic reservoir where they verified the existence of petroleum, producing as much as $1500 \mathrm{bbl} /$ day from two separate zones, as well as natural gas production of as much as 20 MMSCFD also from two zones (Marnelis et al., 2007). Despite that this reservoir is located offshore at a water depth of 250 to $300 \mathrm{~m}$ (820-984 ft), the proximity to the coast makes it a very good candidate for exploitation after the establishment of a drilling network.

Major buried anticlines, characterizing the Ionian Sea area, corresponding to the Ionian and pre-Apulian zones and the Apulian platform, were recognized from the published interpretations of the offshore seismic profiles carried out in the Ionian Sea (Sancho et al., 1972; Sorel et al., 1976; Monopolis and Bruneton, 1982; C. Auroux, 1984, personal communication; Mascle et al., 1984; M. Cushing, 1985, personal communication; Kokinou 2002; Figures 12-14). Examples are as follows:

1. The structures recognized in the pre-Apulian (Paxos) zone west of Kerkyra (Monopolis and Bruneton 2 profile in Figure 13), most probably contain light petroleum, similar to that in the Aquila field (Italy) (Karakitsios and Rigakis, 2007).

2. The structures recognized in Ionian and preApulian zones by the Ion-7 seismic profile were interpreted by Kokinou (2002) (see upper part of Figure 14). The expected reservoir rocks of both Ionian and pre-Apulian sequences are eroded Mesozoic-Eocene carbonates. In the lower part of Figure 14 are presented the possible hydrocarbon accumulations that could be sealed by the thick overlying NeogeneQuaternary sedimentary succession (including, in general, Messinian evaporites) and, partially, by Triassic evaporites. Another possible accumulation is the subevaporite high of the Paleozoic basement, which is caused by the overthrust boundary between the Ionian and pre-
Apulian zones. The eastern part of Figure 14 seismic profile covers a part of the western Patras Gulf, where, in 1996, the Enterprise Oil Company conducted seismic surveys and onshore drillings (described in the "Onshore Sites" subsection). The seismic surveys have detected interesting oil-prone geologic structures.

3 . The very promising major submarine anticlines, located in the Greek domain of the Apulian platform, are observed on the interpreted offshore seismic sections (Auroux 5 profile in Figure 13).

As most of the seismic surveys that have been conducted are of outdated technology, all the aforementioned cases show clearly that before the identification of any possible hydrocarbon site in the offshore area, it is imperative that a detailed modern three-dimensional seismic study be conducted in selected areas of the Ionian Sea.

\section{UNCONVENTIONAL HYDROCARBON POTENTIAL FROM OIL SHALE AND SHALE GAS RESERVOIRS}

Clearly, we are gradually running out of new sedimentary basins to explore for conventional oil and gas and the reserves of conventional oil, which can be produced cheaply, are limited. This is the reason why many of the major oil companies invest in what are commonly called "unconventional hydrocarbons." Large reserves of these exist, and the main types are oil shales, heavy oil, tar sand, and shale gas. In western Greece, important oil and gas shale reservoirs exist, which must be added to its hydrocarbon potential.

\section{Oil Shales}

Western Greece contains significant underground immature, or close to the early maturation stage, source rocks with black shale composition. These source rock oils may be produced by applying an in-situ conversion process. For example, the thermally conductive in-situ conversion technology, developed by Shell (Bartis et al., 2005), involves 


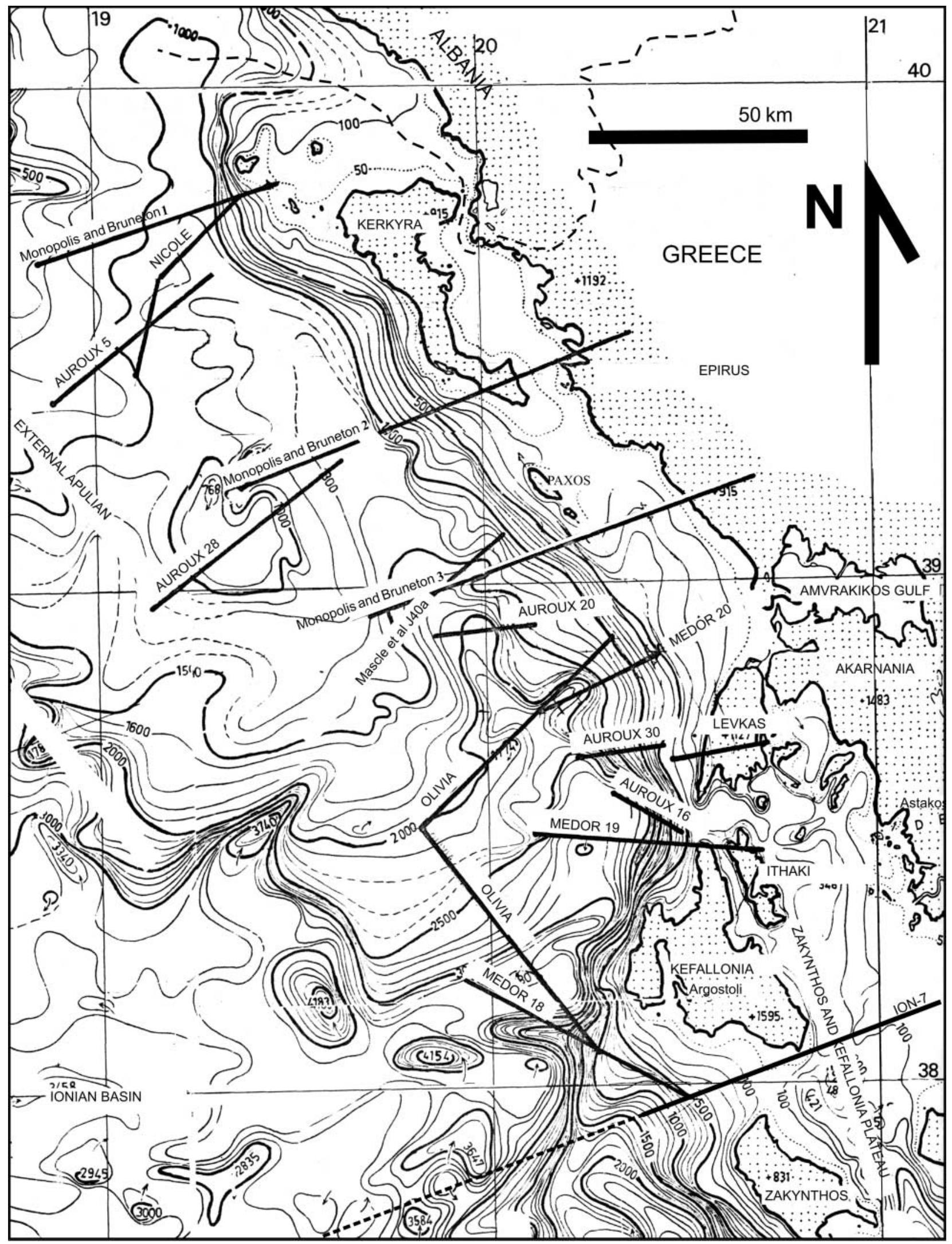

Figure 12. Location of the published seismic lines in the Ionian Sea (Sancho et al., 1972; Sorel et al., 1976; Monopolis and Bruneton, 1982; C. Auroux, 1984, personal communication; Mascle et al., 1984; M. Cushing, 1985, personal communication; Kokinou, 2002). Contour lines refer to the isobaths. 


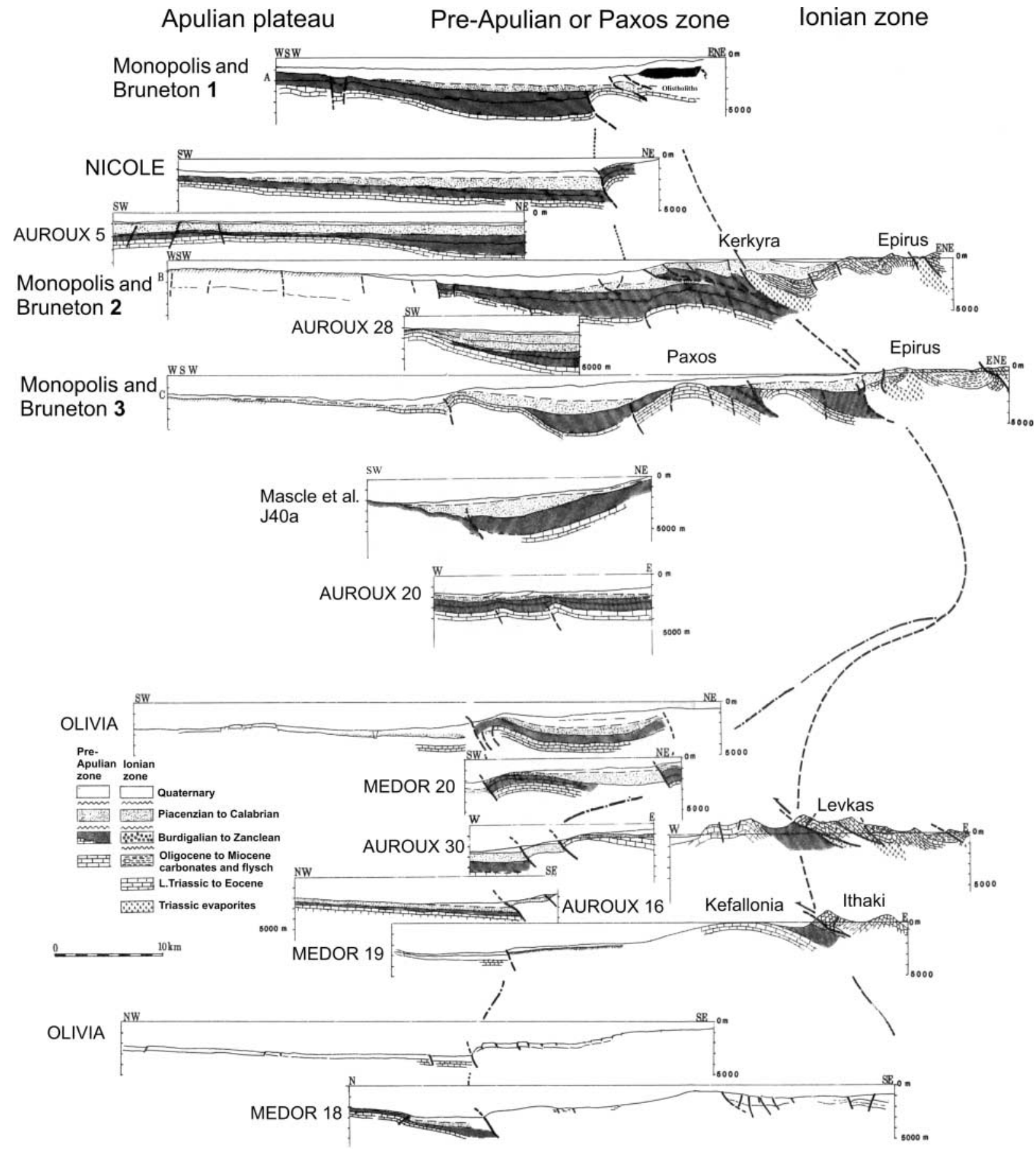

Figure 13. Published interpretations of the offshore seismic profiles (Figure 12) conducted in the lonian Sea (modified by Karakitsios 1990). The mentioned seismic sections were initially interpreted, respectively: AUROUX, from C. Auroux (1984, personal communication); Mascle et al. (J40a), from Mascle et al. (1984); MEDOR 18 and 19, from M. Cushing (1985, personal communication); MEDOR 20, from Sorel et al. (1976), modified from M. Cushing (1985, personal communication); Monopolis and Bruneton, from Monopolis and Bruneton (1982); and NICOLE and OLIVIA, from Sancho et al. (1972).

heating underground oil shale, using electric heaters placed in deep vertical holes drilled through a section of oil shale; the volume of oil shale is heated over a period of 2 to $3 \mathrm{yr}$, until it reaches 340 to $370^{\circ} \mathrm{C}$, at which point, oil is released from the shale. The released product is gathered in collection wells positioned within the heated zone. The current plan of Shell involves the use of ground-freezing 


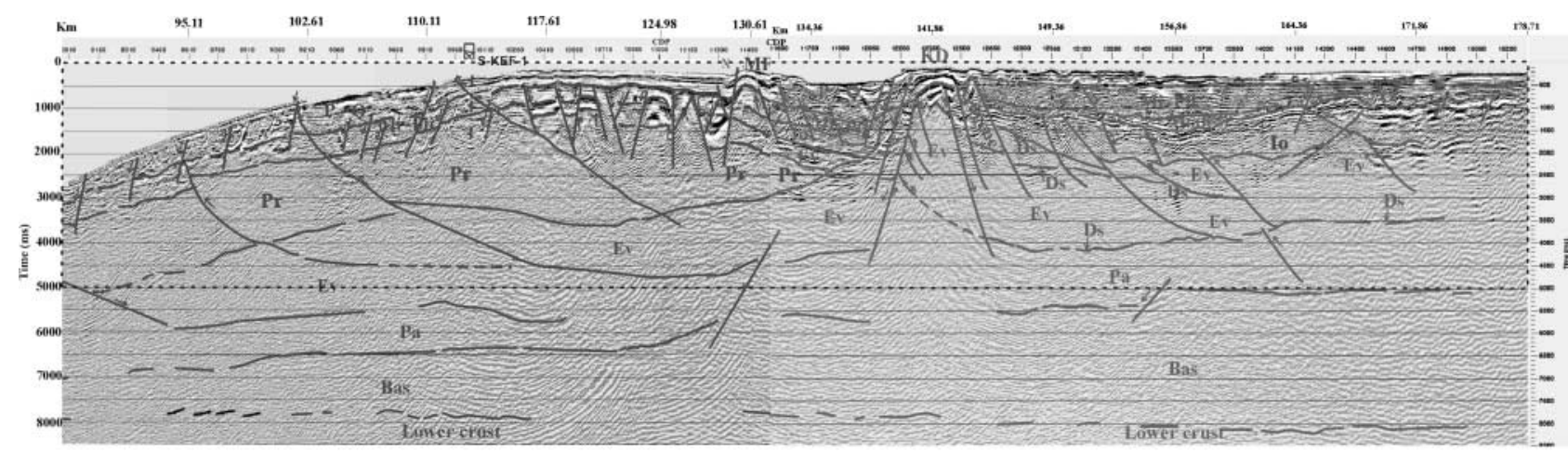

P-Q: Pliocene - Quaternary Mi-Pli: Upper Miocene - Lower Pliocene Mi.d(?): Middle Miocene

lo: Ionian zone calcareous sequence

Pr: Pre-Apulian zone calcareous sequence

Ev: Triassic evaporites

Pa: Paleozoic

Bas: Crystalline basement
Ds: Decollement surface $\mathrm{KD}$ : Kefallonia diapir MF: Mounta fault

日 S-KEF-1: South Kefallonia well

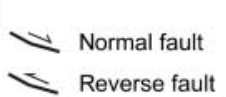

$\sim$ Reverse fault

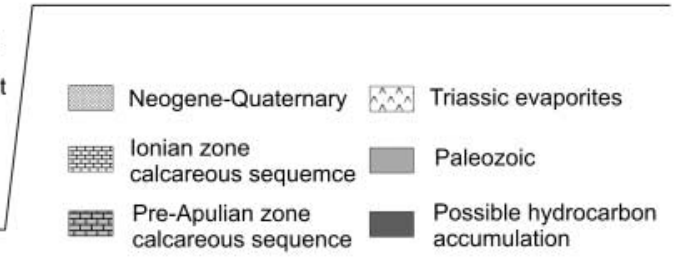

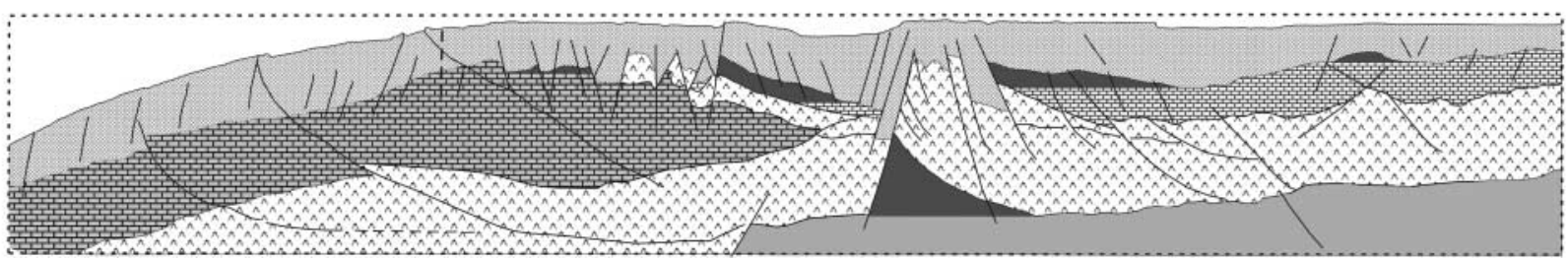

Figure 14. (Upper part) ION-7 seismic profile (used with permission from Kokinou, 2002). The trace of the seismic line is shown in Figure 12. (Lower part) Interpretation: possible hydrocarbon accumulations. Expected reservoir rocks of both lonian and pre-Apulian sequences are eroded Mesozoic-Eocene carbonates, which could be sealed by the thick overlying Neogene-Quaternary sedimentary succession and, partially, by Triassic evaporites. Another possible accumulation is the subevaporite high of the Paleozoic basement (caused by the overthrust boundary between the lonian and pre-Apulian zones) sealed by the Triassic evaporites. In this case, the source rocks may be the Triassic shales in the evaporitic sequence or the Paleozoic sediments.

technology to establish an underground barrier called a "freeze wall" around the perimeter of the extraction zone. The freeze wall prevents groundwater from entering the extraction zone and keeps hydrocarbons and other products generated by the in-situ retorting from leaving the project perimeter during ground heating, product extraction, and postextraction ground cooling. This modern technology is yet unproven at a commercial scale but is regarded by the U.S. Department of Energy as a very promising technology. Nevertheless, in most of western Greece, as previously mentioned, source rocks are black shales with high organic content (TOC). Some that are immature or close to the maturity limit have sufficient thickness and are located below 1500-m (4921-ft) depth can be converted artificially by in-situ heating (pyrolysis) generally to 350 to $500^{\circ} \mathrm{C}$ so that most of the petroleum can be generated from the contained kerogen. In west- ern Greece, several extensive areas with these characteristics exist, which may be subject of exploitation in the future. The map of the Epirus region (IGRS-IFP, 1966) clearly indicates extensive areas where the formations containing source rocks are covered by overburden sediments of more than $1000 \mathrm{~m}(3281 \mathrm{ft})$ thick. The subsurface geometry of these source rocks needs modern seismic studies.

\section{Shale Gas}

Shale gas reservoirs are possible in all areas where shales occur below the groundwater level, with significant extent and organic matter content greater than $1 \%$, and during their geologic history, were found under conditions corresponding to the gas window (generally corresponding to depths over 5000 


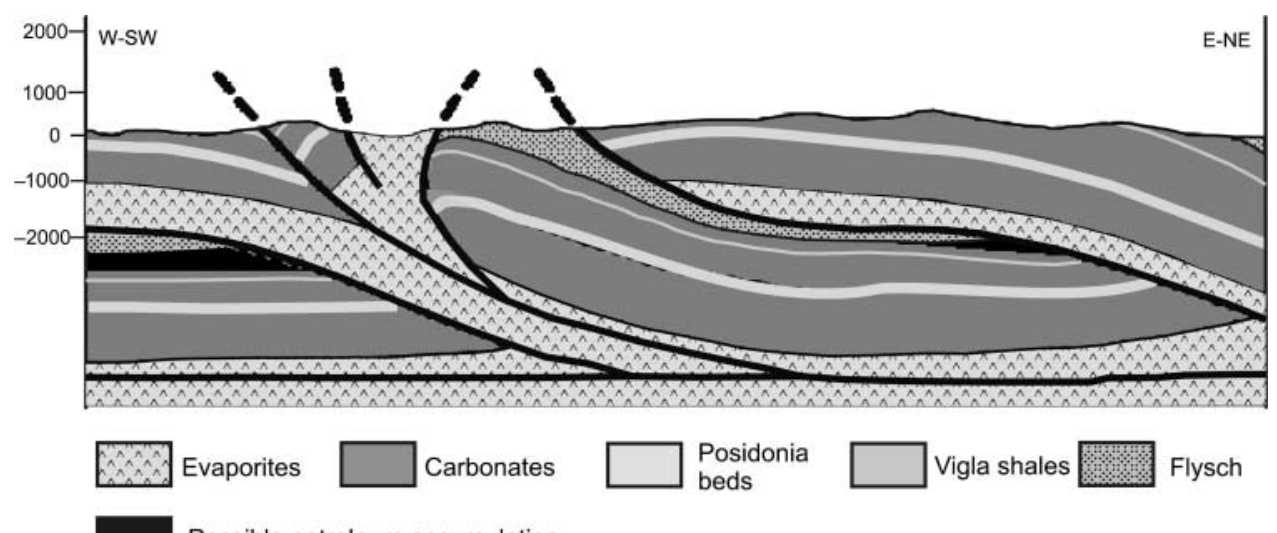

Figure 15. Schematic duplex structures in the lonian zone.

Possible petroleum accumulation

to $6000 \mathrm{~m}[16,404-19,685 \mathrm{ft}])$. Western Greece contains argillaceous source rocks, found within the gas window, from which shale gas may be produced and, consequently, these rocks represent exploitable shale gas reservoirs.

In the Ionian and pre-Apulian zones, shale gas reservoirs constitute the following:

1. The shale layers were intercalated in the subsurface evaporites of the Ionian (Triassic) and preApulian (Triassic-Early Jurassic) zones, respectively, as they entered the gas window (Rigakis et al., 2004; Karakitsios and Rigakis, 2007). The subsurface geometry of these shale layers is unknown and may be revealed only by detailed seismic exploration.

2. The Posidonia beds (Jurassic), which entered the oil window in the central and external Ionian zone (Rigakis and Karakitsios, 1998; Karakitsios and Rigakis, 1996, 2007), are expected to have entered the gas window in the internal Ionian (Epirus-Akarnania syncline; Figure 8) because of the great thickness of the overlying sediments (the flysch alone is $>4000 \mathrm{~m}[13,123 \mathrm{ft}$ ] thick). For the same reasons, the Vigla shale member may sometimes be in the gas window. The subsurface extent and geometry of these shale gas reservoirs needs equally detailed seismic analysis. Additionally, the source rocks of the Ionian zone that are found in the lower tectonic block of the thrust duplexes, which commonly occur in the Ionian zone (Figure 15), may constitute shale gas reservoirs. In this case, the upper tectonic block of the thrust duplex duplicates thickness of the overlying sediments to the lower-block source rocks and, consequently, their entrance to the gas window. Again, the subsurface extension and geometry of the corresponding shale gas reservoirs needs detailed seismic analysis.

\section{CONCLUSIONS}

Western Greece contains major petroleum systems, including offshore in the Ionian Sea.

The main source rocks are

- organic-rich shales in the Triassic evaporite series of the Ionian, pre-Apulian, and Apulian zones;

- black shales (mainly) in the Jurassic formations of both the Ionian and pre-Apulian zones;

- black shales in the Cretaceous formations of the Ionian zone; and

- source rocks of minor importance in the OligoceneNeogene clastic formations of the Ionian, preApulian, and Apulian zones.

The Western Greece and Ionian Sea domain reservoirs are

- Lower Jurassic and Upper Cretaceous-Eocene carbonate rocks of the Ionian zone;

- Gavrovo platform carbonates close to its transition to the Ionian zone;

- Cretaceous chalk in the pre-Apulian zone; 
- secondary fracture porosity in the thrust zones of the Ionian and pre-Apulian domain;

- the entire Apulian carbonate platform, where carbonate deposition in a high-energy shallowwater environment created good porosity and permeability zones at several stratigraphic levels of the carbonate sequence; and

- several clastic horizons in the flysch and/or flyschoid series.

The main seal formations are the Triassic evaporites and the flysch and/or flyschoid deposits.

Possible hydrocarbon accumulations of these petroleum systems are the large onshore and offshore anticlinal areas. Both the Ionian and pre-Apulian zone petroleum systems, as well as those in the Apulian platform, contribute to the possible offshore hydrocarbon accumulations of the Ionian Sea. These areas need three-dimensional seismic exploration.

In addition, western Greece contains significant oil and gas shale reservoirs, which can be explored through nonconventional means. Exploration for conventional petroleum reservoirs, through the interpretation of seismic profiles and the surface geologic data, will simultaneously provide the subsurface geometry of the unconventional reservoirs. Their exploration should follow that of conventional hydrocarbons.

\section{REFERENCES CITED}

Accordi, G., C. Federico, and J. Pignatti, 1998, Depositional history of a Paleogene carbonate ramp (western Cephalonia, Ionian Islands, Greece): Geologica Romana, v. 34, p. 131205.

Allen, P. A., P. Homewood, and G. D. Williams, 1986, Foreland basins: An introduction, in P. A. Allen and P. Homewood, eds., Foreland basins: International Association of Sedimentologists Special Publication 8, p. 3-12.

Aubouin, J., 1959, Contribution à l'étude géologique de la Grèce septentrionale: les confins de l'Epire et de la Thessalie: Annales Géologiques des Pays Helléniques, v. 9, p. 1483.

Bartis J. T., T. Latourrette, L. Dixon, D. J. Peterson, and G. Cecchine, 2005, Oil shale development in the United States: Prospect and policy issues (prepared for the National Energy Technology Laboratory of the U.S. Department of Energy): Santa Monica, California, RAND Corporation, $65 \mathrm{p}$.

Bassoullet, J. P., S. Elmi, A. Poisson, L. E. Ricou, F. Cecca, Y.
Bellion, R. Guiraud, and F. Baudin, 1993, Mid Toarcian (184 to $182 \mathrm{Ma}$ ), in J. Dercourt, L. E. Ricou, and B. Vrielynck, eds., Atlas Tethys, palaeoenvironmental maps: Explanatory notes: Paris, France, Gauthier-Villars, p. 63-84.

Baudin, F., and G. Lachkar, 1990, Géochimie organique et palynologie du Lias supérieur en zone ionienne (Grèce): Exemple d'une sédimentation anoxique conserve dans une paléomarge en distension: Bulletin de la Société Géologique de France, v. 8, no. 6/1, p. 123-132.

Bellas, S. M., 1997, Calcareous nannofossils of the Tertiary flysch (post-Eocene to early Miocene) of the Ionian zone in Epirus, NW Greece: Taxonomy and biostratigraphical correlations: Ph.D. thesis, Selbstverlag Fachbereich Geowissenschaftlichten, Berlin, Germany, p. 1-173.

Bernoulli, D., 2001, Mesozoic-Tertiary carbonate platforms, slopes and basins of the external Apennines and Sicily, in G. B. Vai and P. Martini, eds., Anatomy of an orogen: The Apennines and adjacent Mediterranean basins: Dordrecht, Netherlands, Kluwer Academic Publishers, p. 307-325.

Bonneau, M., 1982, Évolution géodynamique de l'arc égéen depuis le Jurassique supérieur jusqu'au Miocène: Bulletin de la Société Géologique de France, v. 24, p. 229-242.

Bornovas, J., 1964, Geological study of Levkas Island: Geological and geophysical research: Institute for Geological and Subsurface Research (now Institute of Geology and Mineral Exploration) Report 1 (II), p. 1-142.

Bosellini, A., 2002, Dinosaurs "rewrite" the geodynamics of the eastern Mediterranean and the paleogeography of the Apulian platform: Earth-Science Reviews, v. 59, p. 211-234, doi:10.1016/S0012-8252(02)00075-2.

Bosellini, A., and K. J. Hsü, 1973, Mediterranean plate tectonics and Triassic palaeogeography: Nature, v. 224, p. 144-146, doi:10.1038/244144a0.

Bosellini, A., M. Morsilli, and C. Neri, 1999a, Long-term event stratigraphy of the Apulian platform margin (Upper Jurassic to Eocene Gargano, southern Italy): Journal of Sedimentary Research, v. 69, p. 1241-1252, doi:10.2110 /jsr.69.1241.

Bosellini, A., F. R. Bosellini, M. L. Colalongo, M. Parente, A. Russo, and A. Vescogni, 1999b, Stratigraphic architecture of the Salento coast from Capo d'Otranto to S. Maria di Leuca (Apulian, southern Italy): Rivista Italiana di Paleontologia e Stratigrafia, v. 105, p. 397-416.

BP (British Petroleum) Co., Ltd, 1971, The geological results of petroleum exploration in western Greece: Institute for Geology and Subsurface Research (now Institute of Geology and Mineral Exploration) Special Report 10, p. 1-73.

Channell, J. E. T., B. d'Argenio, and F. Horvath, 1979, Adria, the African promontory, in Mesozoic Mediterranean paleogeography: Earth-Science Reviews, v. 15, p. 213292, doi:10.1016/0012-8252(79)90083-7.

Chiotis, S., 1983, Contribution of organic geochemistry to the oil exploration in Greece: Proceedings of the 1st Geological Congress: Bulletin of the Geological Society of Greece, v. 1, p. 203-217.

d'Argenio, B., 1971, Evoluzione geotettonica comparata tra alcune piattaforme carboniche dei Mediterranei Europeo e Americano: Atti della Accademia Pontaniana, v. 20, p. 3-34. 
d'Argenio, B., 1976, Le piattaforme carboniche: Una rassegna di problemi nel quadro geodinamico Mesozoico dell'area Mediterranea: Geological Society of Italy Memoir 13, p. 1-28.

de Graciansky, P. C., G. Dardeau, M. Lemoine, and P. Tricart, 1989, The inverted margin of the French Alps and foreland basin inversion, in M. A. Cooper and G. D. Williams, eds., Inversion tectonics: Geological Society (London) Special Publication 44, p. 87-104.

Finetti, I., 1982, Structure, stratigraphy and evolution of the central Mediterranean Sea: Bolletino di Geofisica Teorica ed Applicata, v. 24, p. 247-312.

Flores, G., M. Pieri, and G. Sestini, 1991, Geodynamic history and petroleum habitats of the South-East Adriatic region, in A. M. Spencer, ed., Generation, accumulation, and production of Europe's hydrocarbons: European Association of Petroleum Geologists Special Publication 1, p. 389-398.

Graham Wall, B. R., R. Girbaces, A. Mesonjesi, and A. Aydin, 2006, Evolution of fracture and fault-controlled fluid pathways in carbonates of the Albanides fold-thrust belt: AAPG Bulletin, v. 90, p. 1227-1249, doi:10.1306/03280604014.

Herodotus, 484-430 B.C. Histories: Book D, verse 195.

IGRS-IFP (Institut de Géologie et Recherches du Sous-solInstitut Français du Pétrole), 1966, Etude géologique de l'Epire (Grèce nord-occidentale): Technip eds., Paris, 306 p.

Jenkyns, H. C., 1988, The early Toarcian (Jurassic) anoxic event: Stratigraphic, sedimentary, and geochemical evidence: American Journal of Sciences, v. 288, p. 101-151.

Kamberis, E., F. Marnelis, M. Loucoyannakis, F. Maltezou, A. Hirn, and Streamers Group, 1996, Structure and deformation of the external Hellenides based on seismic data from offshore western Greece, in G. Wessely and W. Liebl, eds., Oil and gas in Alpidic thrustbelts and basins of central and eastern Europe: European Association of Geoscientists and Engineers Special Publication 5, 207-214.

Karakitsios, V., 1990, Chronologie et géométrie de l'ouverture d'un bassin et de son inversion tectonique: Le bassin ionien (Epire, Grèce): Ph.D. thesis, University of Pierre and Marie Curie, Paris, France, 310 p.

Karakitsios, V., 1992, Ouverture et inversion tectonique du basin Ionien (Epire, Grèce): Annales Géologiques des Pays Helléniques, v. 35, p. 185-318.

Karakitsios, V., 1995, The influence of preexisting structure and halokinesis on organic matter preservation and thrust system evolution in the Ionian basin, northwestern Greece: AAPG Bulletin, v. 79, p. 960-980.

Karakitsios, V., and L. Koletti, 1992, Critical revision of the age of the basal Vigla limestones (Ionian zone, western Greece), based on nannoplankton and calpionellids, with paleogeographical consequences, in B. Hamrsmid and J. Young, eds., Proceedings of the 4th International Nannoplankton Association Conference, Prague, Czech Republic: Knihovnicka Zemniho Plynu a Nafty, September 1991, v. 14a, p. 165-177.

Karakitsios, V., and F. Pomoni-Papaioannou, 1998, Sedimentological study of the Triassic solution-collapse breccias of the Ionian zone (NW Greece). Carbonates \& Evaporites, v. 13, no. 2, p. 207-218, doi:10.1007/BF03176594.

Karakitsios, V., and N. Rigakis, 1996, New oil source rocks cut in Greek Ionian basin: Oil \& Gas Journal, v. 94, no. 7, p. 56-59.
Karakitsios, V., and N. Rigakis, 2007, Evolution and petroleum potential of western Greece: Journal of Petroleum Geology, v. 30, no. 3, p. 197-218, doi:10.1111/j.1747-5457 .2007.00197.x.

Karakitsios, V., T. Danelian, and P. De Wever, 1988, Datations par les radiolaires des calcaires à filaments, schistes à Posidonies supérieurs et calcaires de Vigla (zone Ionienne, Epire, Grèce) du Callovien au Tithonique terminal: Compte Rendu Académie des Sciences, v. 306, no. 2, p. 367-372.

Karakitsios, V., N. Rigakis, and I. Bakopoulos, 2001, Migration and trapping of the Ionian series hydrocarbons (Epirus, NW Greece): Bulletin of the Geological Society of Greece, v. 34, no. 3, p. 1237-1245.

Karakitsios, V., H. Tsikos, Y. van Breugel, I. Bakopoulos, and L. Koletti, 2004, Cretaceous oceanic anoxic events in western continental Greece: Bulletin of the Geological Society of Greece, v. 34, no. 2, p. 846-855.

Karakitsios, V., H. Tsikos, Y. Van Breugel, L. Koletti, J. S. Sinninghe Damste, and H. C. Jenkyns, 2007a, First evidence for the CenomanianTuronian oceanic anoxic event (OAE2 or "Bonarelli" event) from the Ionian zone, western continental Greece: International Journal of Earth Sciences, v. 96, p. 343-352, doi:10.1007 /s00531-006-0096-4.

Karakitsios, V., H. Tsikos, K. Agiadi-Katsiaouni, S. Dermitzoglou, and E. Chatziharalambous, 2007b, The use of carbon and oxygen stable isotopes in the study of global palaeoceanographic changes: Examples from the Cretaceous sediment rocks of western Greece: Bulletin of the Geological Society of Greece v. 39, p. 45-59.

Karakitsios, V., N. Kafousia, and H. Tsikos, 2010a, Oceanic anoxic events as recorded in the Mesozoic sedimentary record of mainland Greece: Hellenic Journal of Geosciences, v. 45, p. 123-131.

Karakitsios, V., M. Triantaphyllou, and P. Panoussi, 2010b, Preliminary study on the slump structures of the early Oligocene sediments of the pre-Apulian zone (Antipaxos Island, northwestern Greece): Bulletin of the Geological Society of Greece, v. 43, no. 2, p. 634-642.

Kokinou, E., 2002, Processing and interpretation of deep seismic reflection data in the Ionian Sea: Ph.D. thesis, Technical University of Crete, Crete, Greece, p. 1261.

Kokinou, E., E. Kamberis, A. Vafidis, D. Monopolis, G. Ananiadis, and A. Zelilidis, 2005, Deep seismic reflection data from offshore western Greece: A new crustal model for the Ionian Sea: Journal of Petroleum Geology, v. 28, no. 2, p. 185-202, doi:10.1111/j.1747-5457 .2005.tb00079.x.

Laubscher, H. P., 1978, Foreland folding: Tectonophysics, v. 47, p. 325-337, doi:10.1016/0040-1951(78)90037-9.

Magoon, L. B., and W. G. Dow, eds., 1994, The petroleum system: From source to trap: AAPG Memoir 60, 655 p.

Makris, J., 1977, Geophysical investigations of the Hellenides: Hamburger Geophysikalische Einzelschriften, v. 34, p. 124.

Maravelis, A., G. Makrodimitras, N. Pasadakis, and A. Zelilidis, in press, Stratigraphic evolution and source rock potential of a lower Oligocenelower/middle Miocene continental 
slope system, Greek fold-and-thrust belt, Ionian Sea, northwestern Greece: Geological Magazine.

Maravelis, A., G. Makrodimitras, and A. Zelilidis, 2012, Hydrocarbon prospectivity in the Apulian platform and Ionian zone, in relation to strike-slip fault zones, foreland and back-thrust basins of Ionian thrust, in Greece: Oil and Gas European Magazine, v. 38, no. 2, p. 64-89.

Marnelis, F., N. Roussos, N. Rigakis, and V. Karakitsios, 2007, Structural geology of the western Greece fold-and-thrust belt: AAPG and AAPG European Region Energy Conference and Exhibition 2007, Athens, Greece, November 14 17, 2007, Guide to Fieldtrip 1, 29 p.

Mascle, J., C. Auroux, and S. Rossi, 1984, Structure géologique superficielle et évolution récente de la dorsale apulienne (Mer Ionienne): Revue de l'Institut Français du Pétrole, v. 39, no. 2, p. 127-142.

Mattavelli, L., and L. Novelli, 1990, Geochemistry and habitat of the oils in Italy: AAPG Bulletin, v. 74, p. 16231639.

Mattavelli, L., M. Pieri, and G. Groppi, 1993, Petroleum exploration in Italy: A review: Marine and Petroleum Geology, v. 10, p. 410-425, doi:10.1016/0264-8172(93)90044-S.

Mavromatidis, A., and V. C. Kelessidis, 2009, Investigations into the causes of high formation pressures in deep drilling in western Greece: Mineral Wealth, v. 153, p. 9-21.

Mavromatidis, A., V. C. Kelessidis, and D. G. Monopolis, 2004, A review of recent hydrocarbon exploration in Greece and its potential: 1st International Conference on Advances in Mineral Resource Management and Environmental Geotechnology, Chania, Greece, June 7-9, 2004, p. 1-8.

Monopolis, D. G., 1977, Oil exploration in Greece: Proceedings of the Conference "The Energy Problem of Greek Economy Today," organized by the Technical Chamber of Greece, Athens, Greece, May 23-28, 1977 p. 1-7.

Monopolis, D., and A. Bruneton, 1982, Ionian Sea (western Greece): Its structural outline deduced from drilling and geophysical data: Tectonophysics, v. 83, p. 227-242, doi:10.1016/0040-1951(82)90020-8.

Mostrardini, F., and S. Merlini, 1986, Appennino centromeridionale, sezioni geologich e proposta di modello strutturale: Geological Society of Italy Memoir 35, p. 177202.

Palakas, J. G., D. Monopolis, C. A. Nicolaou, and D. E. Anders, 1986, Geochemical correlation of surface and subsurface oils, western Greece, in D. Leythaeuser and J. Rullkotter, eds., Advances in organic geochemistry 1985: Organic Geochemistry, v. 10, p. 417-423, doi:10.1016/0146 -6380(86)90041-0.

Picha, F. J., 1996, Exploring for hydrocarbons under thrust belts: A challenging new frontier in the Carpathians and elsewhere: AAPG Bulletin, v. 80, p. 1547-1564.

Pieri, M., 1969, Exploration for oil and gas in Italy, in P. Hepple, ed., The exploration for petroleum in Europe and North Africa: London, United Kingdom, Institute of Petroleum, p. 87-111.

Pieri, M., and L. Mattavelli, 1986, Geologic framework of Italian petroleum resources: AAPG Bulletin, v. 70, no. 2, p. 103130.

Pomoni-Papaioannou, F., V. Karakitsios, E. Kamberis, and F. Marnelis, 2004, Chevron-type halite and nodular anhy- drite in the Triassic subsurface evaporites of the Ionian zone (western Greece): Bulletin of the Geological Society of Greece, v. 36, no. 1, p. 578-586.

Ricci Lucchi, F., 1986, The Oligocene to recent foreland basins of the northern Appenines, in P. A. Allen and P. Homewood, eds., Foreland basins: International Association of Sedimentologists Special Publication 8, p. 101-139.

Rigassi, D., 1977, Genèse tectonique du Jura: Une nouvelle hypothèse: Paleolab News, v. 2, p. 1-27.

Rigakis, N., and V. Karakitsios, 1998, The source rock horizons of the Ionian basin (NW Greece). Marine and Petroleum Geology, v. 15, p. 593-617, doi:10.1016/S0264-8172 (98)00032-4.

Rigakis, N., Th. Noussinanos, F. Marnelis, and V. Karakitsios, 2004, Oil potential of pre-Apulian zone (ext. abs.): 10th International Congress of the Geological Society of Greece, Thessaloniki, Greece, April 15-17, 2004, p. 576-577.

Roure, F., I. Fili, S. Nazaj, J. P. Cadet, K. Mushka, and M. Bonneau, 2004, Kinematic and petroleum systems: An appraisal of the outer Albanides, in K. R. McClay, ed., Thrust tectonics and hydrocarbon systems: AAPG Memoir 82, p. 474-493.

Roussos, N., and F. Marnelis, 1995, Greece licensing round to focus on western sedimentary basins: Oil \& Gas Journal, v. 93 , no. 10 , p. $58-62$.

Rubert, Y., J. Mohamed, L. Corinne, A. Cerepi, G. Foto, and K. Muska, 2012, Sedimentology of resedimented carbonates: Facies and geometrical characterization of an Upper Cretaceous calciturbidite system in Albania: Sedimentary Geology, v. 257260, p. 63-77, doi:10.1016/j.sedgeo.2012 .02.009.

Sancho, J., J. Letouzey, B. Biju-Duval, P. Courrier, L. Montadert, and E. Winnock, 1972, New data on the eastern Mediterranean basin from seismic reflection: Rapport de l'Institut Français du Pétrole, Division Géologie, v. 20, p. 1-676.

Smith, A. G., and E. N. Moores, 1974, Hellenides, in A. M. Spencer, ed., Mesozoic and Cenozoic orogenic belts: Geological Society (London) Special Publication 4, p. 159-185.

Sorel, D., W. D. Nestoroff, J. Limond, F. Lemeille, and M. Sembrier, 1976, Mise en évidence de structures compressives sous-marines Plio-Pléistocènes dans l'arc égéen externe au large de Levkas (Iles Ioniennes, Grèce): Compte Rendu Académie des Sciences, v. 282, no. 23, Série D, p. 2045-2048.

Tsikos, H., et al., 2004, Organic carbon deposition in the Cretaceous of the Ionian basin, NW Greece: The Paquier Event (OAElb) revisited: Geological Magazine, v. 141, no. 4, p. 401-416.

Underhill, J. R., 1988, Triassic evaporites and Plio-Quaternary diapirism in western Greece: Journal of the Geological Society, v. 145, p. 269-282, doi:10.1144/gsjgs.145.2.0269.

Underhill, J. R., 1989, Late Cenozoic deformation of the Hellenide foreland, western Greece: Geological Society of America Bulletin, v. 101, p. 613-634, doi:10.1130 /0016-7606(1989)101<0613:LCDOTH>2.3.CO;2.

van Greet, M., R. Swennen, C. Durmishi, F. Roure, and Ph. Muchez, 2002, Paragenesis of Cretaceous to Eocene carbonate reservoirs in the Ionian foreland fold-and-thrust belt (Albania): Relation between tectonism and fluid 
flow: Sedimentology, v. 49, p. 697-718, doi:10.1046/j .1365-3091.2002.00476.x.

Vilasi, N., J. Malandain, L. Barrier, J. P. Callot, N. Guilhaumou, O. Lacombe, K. Muska, F. Roure, and R. Swennen, 2009, From outcrop and petrographic studies to basin-scale fluid flow modeling: The use of the Albanian natural laboratory for carbonate reservoir characterization: Tectonophysics, v. 474, p. 367-392, doi:10.1016/j .tecto.2009.01.033.

Williams, G. D., 1985, Microfractures in chalks of Albuskjell field, Norwegian sector, North Sea: Possible origin and distribution: AAPG Bulletin, v. 67, p. 201-234.
Xenopoulos, S., 2000, Exploration and exploitation of hydrocarbons in Greece: Current activities-Perspectives: Proceedings of the 3rd Conference on Mineral Resources, Athens, Greece, November 22-23, 2000, p. 35-42.

Zappaterra, E., 1994, Source rock distribution model of the peri-Adriatic region: AAPG Bulletin, v. 78, no. 3, p. 333354.

Zelilidis, A., D. J. W. Piper, I. Vakalas, P. Avramidis, and K. Getsos, 2003, Oil and gas plays in Albania: Do equivalent plays exist in Greece? Journal of Petroleum Geology, v. 26 , no. 1, p. 29-48, doi:10.1111/j.1747-5457.2003 .tb00016.x. 